\title{
Long-term trends of nitrogen and phosphorus mass balances on New York State dairy farms
}

\author{
Sebastian Cela, Quirine M. Ketterings, ${ }^{1}$ Karl Czymmek, Melanie Soberon, and Caroline Rasmussen
}

Department of Animal Science, Cornell University, Ithaca, NY 14853

\begin{abstract}
The whole-farm nutrient mass balance (NMB) is an adaptive management tool that can be used to identify areas for improvement in nutrient management and to monitor progress over time. The objectives of this study were to (1) evaluate the trends of nitrogen and phosphorus mass balances of 27 New York State dairy farms over 6 to $10 \mathrm{yr}$, (2) identify specific management changes made by 4 case study farms that improved NMB over time by shifting NMB up or down depending on the initial NMB, and (3) evaluate the potential of key indicators to identify opportunities for improvement in NMB. During the study period, milk price fluctuated whereas costs associated with feed and fertilizer increased substantially. Of the 27 farms, 67 to $74 \%$ (depending on the nutrient) decreased NMB per hectare over time, whereas 63 to $67 \%$ decreased NMB per megagram of milk over time. In general, changes in NMB were directionally correct, with 43 to $56 \%$ of farms operating in the optimum operational zone (with both NMB per hectare and per megagram of milk below the feasible levels suggested for New York) toward the end of the study versus 22 to $26 \%$ in the first 2 yr of the assessments. The 4 case study farms improved their NMB, whole-farm nutrient use efficiencies, and feed nutrient use efficiencies while maintaining or increasing milk production per cow. The case study farmers made the largest changes in precision feed management, reducing protein and $\mathrm{P}$ in purchased feed by replacing concentrates with blends with lower nutrient concentrations. Total nutrient imports, feed imports, the percentage of homegrown feed and nutrients, the concentration of nutrients in the purchased feed, fertilizer imports, and overall crop yields were useful in identifying potential areas for improvement in NMB.
\end{abstract}

Key words: dairy farms, nutrient use efficiency, precision feeding, and precision management

Received May 4, 2015.

Accepted June 18, 2015.

${ }^{1}$ Corresponding author: qmk2@cornell.edu

\section{INTRODUCTION}

In 1999, under the Clean Water Act (USDA-EPA, 1999), New York State (NY) introduced its first concentrated animal-feeding operation (CAFO) permit for dairy and livestock farms that exceeded a population threshold. These facilities were defined as point sources of pollution by Environmental Protection Agency rules and the permit requires control of pollutants, including losses of nitrogen and phosphorus from livestock production areas and land under control of the operation that receives manure. In addition, state and federal programs were instituted to assist nonregulated farms to implement comprehensive nutrient management plans (CNMP). The implementation of CNMP and their associated best-management practices contributed to an improvement in NY statewide $\mathrm{P}$ balances over time (Ketterings and Czymmek, 2012). The plan-based CNMP approach takes a very important first step by ensuring enough land base is accessible to reasonably recycle nutrients, but it does not provide a mechanism for farms to measure and manage internal nutrient use efficiency as a way toward nutrient source reduction.

In 2011, the Natural Resources Conservation Service (NRCS) released a Technical Note entitled "Adaptive Nutrient Management" (NRCS, 2013), recognizing that no single nutrient management strategy exists that is optimal for all cropping scenarios. The adaptive management approach promotes adjustments in amount, source, timing, and placement (method of application) of fertilizer and manure to minimize nutrient losses and increase nutrient use efficiency over time. Adaptive management allows farms to set a performance base and then choose a range of practices and approaches to meet goals over time. This approach requires the use of tools and benchmarks to both determine a starting point (performance base) and to evaluate the effect of management changes on performance indicators over time.

Various tools exist for evaluation of management practices at the field or cow level. However, an annual whole-farm nutrient mass balance (NMB) assessment is one of very few on-farm tools to aid in whole-farm 
performance. An NMB is the difference between the nutrients imported onto and those exported from farms, expressed as nutrients per tillable hectares or per megagram of milk production. Negative NMB are undesirable in the long term, whereas a large positive balance may indicate low nutrient use efficiency and high risk of nutrient loss. Although several studies assessed NMB on various agricultural operations in the United States (Anderson and Magdoff, 2000; Spears et al., 2003; Hristov et al., 2006), none included benchmarks or feasibility assessments. Two exceptions include studies in Belgium by Nevens et al. (2006) and in NY by Cela et al. (2014). The latter study characterized the distribution of NMB of 102 dairy farms in $\mathrm{NY}$ in a single year and proposed feasible balances at $\leq 118 \mathrm{~kg}$ of $\mathrm{N} / \mathrm{ha}$ (excluding $\mathrm{N}_{2}$ fixation; N1), $\leq 146 \mathrm{~kg}$ of $\mathrm{N} /$ ha (including $\mathrm{N}_{2}$ fixation and assuming no manure application to legumes; N2), and $\leq 13 \mathrm{~kg}$ of $\mathrm{P} / \mathrm{ha}$, based on the NMB at or below which $75 \%$ of the farms operated in the study. Cela et al. (2014) also reported feasible balances per megagram of milk at $\leq 8.8 \mathrm{~kg}$ of $\mathrm{N} / \mathrm{Mg}$ for $\mathrm{N} 1, \leq 11.8 \mathrm{~kg}$ of $\mathrm{N} / \mathrm{Mg}$ for $\mathrm{N} 2$, and $\leq 1.1 \mathrm{~kg}$ of $\mathrm{P} / \mathrm{Mg}$ based on what $50 \%$ of the farms achieved in that database. Farms that operate with NMB that are below the feasible balances per hectare and per megagram but above zero are defined as farms managed in the optimum operational zone. Farms in the optimum zone have low risk of losing nutrients to the environment as well as high nutrient use efficiencies.

Nutrient mass balances can vary from year to year as they can be influenced by weather conditions, feed and milk prices, and so on. Therefore, to truly evaluate the effect of management changes on NMB, long-term trends need to be analyzed. A study by Soberon et al. (2015) analyzed NMB on $54 \mathrm{NY}$ dairies over 4 to 6 yr and showed that 63 to $76 \%$ of the NMB decreased over time (depending on the nutrient), and $>50 \%$ of the farms did so while increasing milk production per cow. Improvements in balances were primarily due to changes in feed imports. Soberon et al. (2015) identified total nutrient imports, feed nutrient imports, animal density, percentage of homegrown feed, homegrown nutrients fed, and feed nutrient use efficiency as key indicators to identify areas for improvement in NMB. However, the study did not assess specific management changes made at the farm level. Such an assessment will require additional assessment years. The objectives of the current study were to (1) evaluate the evolution of $\mathrm{N}$ and $\mathrm{P}$ mass balances of 27 dairy farms over 6 to $10 \mathrm{yr}$; (2) identify specific management changes made by 4 case study farms, each with at least 8 yr of data, that improved NMB over time while maintaining or increasing milk productions; and (3) evaluate efficiency indicators for their ability to identify opportunities for improvement in NMB.

\section{MATERIALS AND METHODS}

\section{Participating Farms and Selection of Case Study Farms}

Dairy farmers were selected based on their interest in participating and the availability of records to complete the NMB (Cela et al., 2014). In our study, we analyzed $27 \mathrm{NY}$ dairy farms that assessed NMB for 6 to $10 \mathrm{yr}$ between 2003 and 2013 (not all of them in consecutive years), resulting in a total of 193 annual NMB. Farms were located in $9 \mathrm{NY}$ watersheds. The size and management practices varied widely across farms: 20 to 5,003 cows, 36 to 2,703 tillable hectares, 0.5 to 5.1 animal units (AU)/ha, 4.2 to $13.6 \mathrm{Mg}$ of milk/cow per year, 1.6 to $28.1 \mathrm{Mg}$ of milk/ha, and 33 to $98 \%$ of homegrown feed. Eighteen farms were classified as animal feeding operations (AFO; <200 mature dairy cows) and 9 were CAFO (>200 mature dairy cows, USDA-EPA, 1999). Therefore, this database is skewed toward medium and large farms compared with the distribution of all dairy farms in NY (Cela et al., 2014).

From this database, 4 farms with 8 to 10 yr of NMB records (35 NMB) were further evaluated for specific management changes that affected their farm's NMB. The 4 selected farms (1) operated in the last 4 yr with NMB per hectare and per megagram of milk below the feasible $\mathrm{NMB} \pm 10 \%$, (2) had high-performing herds (>10.3 Mg of milk/cow per year) compared with the average of NY dairies in the 2003 to 2010 period (8.7 $\mathrm{Mg} /$ cow per year; USDA-NASS, 2014), (3) maintained or increased total milk produced per farm and per cow over the study period, (4) represented all size-categories (AFO, medium and large CAFO), and (5) illustrated the different NMB trends observed in the larger database (increases, decreases, fluctuations over time).

\section{Characteristics of Case Study Farms}

Farm 1. Farm 1 is a medium CAFO. On average, over the first $2 \mathrm{yr}$ of assessments, it had 630 mature Holstein cows (0.68 heifer-to-cow ratio), 497 tillable ha ( $74 \%$ of which received manure), produced $10.5 \mathrm{Mg}$ of milk/cow per year (Figure 1), had an overall crop yield of $10.7 \mathrm{Mg}$ of $\mathrm{DM} / \mathrm{ha}$, and did not export crops or manure. The typical rotation of the farm was an alfalfa-grass or grass to corn rotation with, within any typical year, 23 to $31 \%$ of the land in alfalfa-grass, 20 to $33 \%$ in grass, and 42 to $51 \%$ of the land in corn, most of which was harvested as silage (Figure 2). In 2006, 

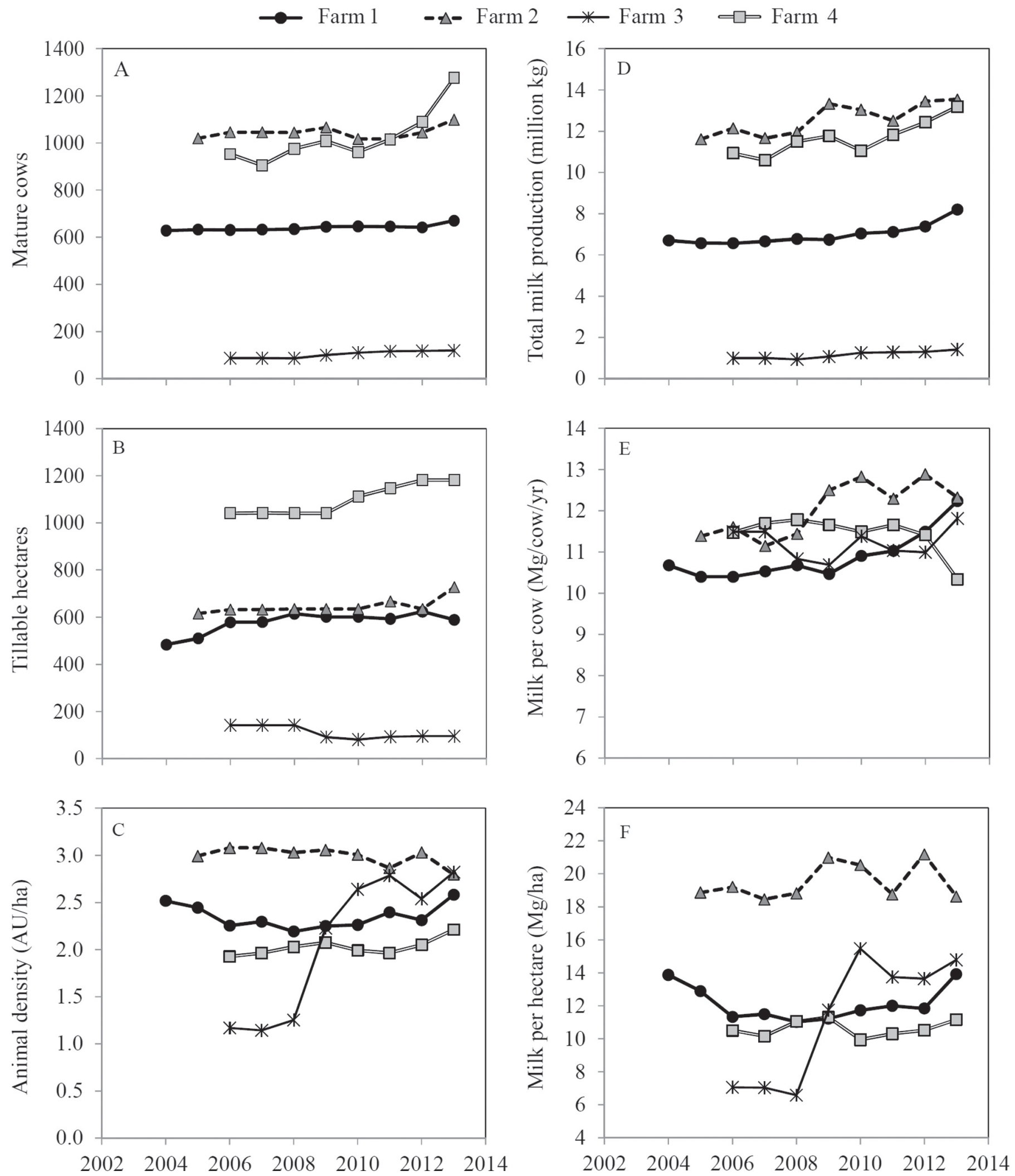

Figure 1. Evolution over time of mature cows (A), tillable hectares (B), animal density (C), and milk production per farm (D), per cow (E), and per hectare (F) for 4 New York case study dairy farms. 

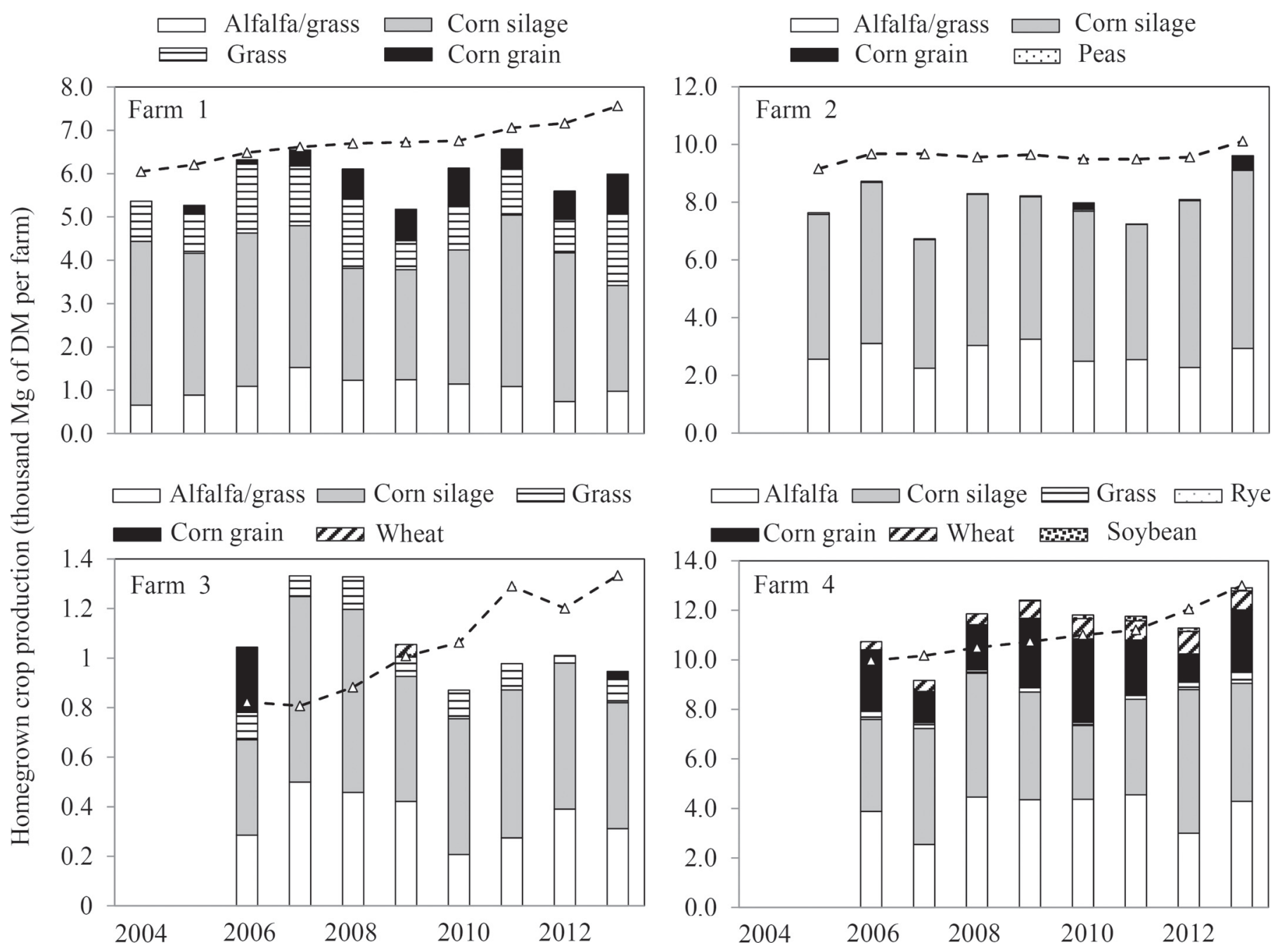

Figure 2. Evolution of the homegrown crop production for 4 New York case study dairy farms. The dotted line is a gross estimation of the annual DM requirements of the herd.

the farmer built a 12.1 million liter manure storage, increasing the time of manure storage from a few days to approximately 6 mo.

Farm 2. Farm 2 is a large CAFO. On average over the first 2 yr of assessments it had 1,033 mature cows (98\% Holstein, 2\% Jersey and other breeds), 0.81 heifer-to-cow ratio, 624 tillable ha (all of which received manure), produced 11.4 Mg of milk/cow per year (Figure 1), had an overall crop yield of $13.1 \mathrm{Mg}$ of $\mathrm{DM} /$ ha, exported 9 and $7 \%$ of the total $\mathrm{N}$ and $\mathrm{P}$ exports as crops, respectively, and 12 and $11 \%$ of the total $\mathrm{N}$ and $\mathrm{P}$ exports as manure, respectively. The typical rotation was a corn and alfalfa or grass hay rotation, including 44 to $57 \%$ of the tillable hectares in corn (of which $>93 \%$ was harvested as silage), 35 to $45 \%$ of the land in alfalfa and grass hay, and a small area $(2-6 \%)$ in peas (Figure 2).
Farm 3. Farm 3 is an AFO. On average over the first $2 \mathrm{yr}$ of assessments, it had 87 Holstein cows $(0.83$ heifer-to-cow ratio), 142 tillable hectares (89\% of which received manure), produced $11.5 \mathrm{Mg}$ of milk/cow per year (Figure 1), had an overall crop yield of $8.4 \mathrm{Mg}$ of $\mathrm{DM} /$ ha, exported $54 \%$ of the total $\mathrm{N}$ and $42 \%$ of the total $\mathrm{P}$ as crops, respectively, and did not export manure. The typical crop rotation was a corn and alfalfa and grass hay rotation, with 34 to $43 \%$ of the area in corn, which was typically harvested for silage, 37 to $54 \%$ in alfalfa-grass, and 10 to $19 \%$ of the area in grass hay. The farm occasionally grew some wheat (Figure 2). Farm 3 went through a major management change in 2009, when the farmer installed 2 robotic milking stations in their existing freestall barn, increased the number of cows, and shifted from milking cows twice a day to 2.7 times/d. A rented portion of Farm 3 land 
base came up for sale shortly after the significant capital investment in the robots, resulting in a reduction of acreage on the farm, as the farm did not have the capital to purchase the land.

Farm 4. Farm 4 is a large CAFO. On average over the first $2 \mathrm{yr}$ of assessments it had 929 cows (90\% Holstein, $5 \%$ Jersey, 5\% Brown Swiss), 0.85 heifer-to-cow ratio, 1,041 tillable hectares ( $90 \%$ of which received manure), produced 11.6 Mg of milk/cow per year (Figure 1), had an overall crop yield of $9.5 \mathrm{Mg}$ of DM/ha, exported 12 to $14 \%$ of the total $\mathrm{N}$ and $\mathrm{P}$ via crops, respectively, and 0 to $1 \%$ of the total $\mathrm{N}$ and $\mathrm{P}$ via manure, respectively. The typical rotation was a corn and alfalfa rotation, including 46 to $52 \%$ of the tillable area in corn, of which 33 to $74 \%$ was harvested as silage, 28 to $36 \%$ of the area in pure alfalfa, 3 to $10 \%$ of the hectares in grass, 9 to $10 \%$ in wheat, and 3 to $5 \%$ in soybeans (Figure 2).

\section{Data Collection}

The NMB data collection process was extensively described in Soberon et al. (2013) and Cela et al. (2014). Briefly, NMB assessments were based on farm records; no additional sample analyses were done. Data were collected for calendar years (from January 1 to December 31). The imports included purchased feed corrected for inventories, fertilizers, animals and bedding, and their respective $\mathrm{N}, \mathrm{P}$, and $\mathrm{K}$ concentrations. The managed exports included milk, animals, crops, and manure. Additional data collected included the number of milk cows, heifers, calves, and their average BW, total farm land (owned plus rented land, including buildings and woodland), tillable land (owned and rented crop land and potentially tillable pasture), legume land (tillable land with $>10 \%$ legumes), land receiving manure (as a percentage of the tillable land), and the quantity and quality of farm-produced grains and forages. After the annual NMB assessments were completed, reports were mailed to the participating farms with comparisons of their NMB per hectare and per megagram of milk with those of their peers in NY. The reports did not include interpretations, advice, or benchmarks.

\section{Calculations}

In our study, the Cornell University NMB calculator (Soberon et al., 2013) was used to calculate the wholefarm NMB. For each farm, an NMB was calculated by adding the nutrients in imported feed, fertilizers, $\mathrm{N}_{2}$ fixation, animals, and bedding, and subtracting exported nutrients in milk, animals, crops, and manure. The NMB were expressed per tillable hectares (reflecting potential for nutrient recycling on the land base) and per megagram of milk produced (reflecting nutrient use efficiency). The estimation of $\mathrm{N}_{2}$ fixation of legumes has a high degree of uncertainty (Oenema et al., 2003; Gourley et al., 2012). For this reason, $2 \mathrm{~N}$ balances were calculated: $\mathrm{N}$ balance without $\mathrm{N}_{2}$ fixation (N1) and $\mathrm{N}$ balance assuming a yield-specific $\mathrm{N}_{2}$ fixation and no manure applications to legume fields (N2). Thus, the actual $\mathrm{N}$ mass balance is somewhere between $\mathrm{N} 1$ and N2. Further details were reported by Cela et al. (2014).

One AU was defined as $454 \mathrm{~kg}$ of live weight across all classes of dairy cattle: cows, heifers, and calves. The animal density (AU/ha) of each farm was calculated as the ratio between the total animal units and the number of tillable hectares. Crop production was calculated by multiplying the yield of each crop (Mg of DM/ ha) by the area harvested (ha). The total farm crop production $(\mathrm{Mg}$ of $\mathrm{DM})$ was obtained by adding the production of all crops within a farm. The overall crop yield $(\mathrm{Mg} / \mathrm{ha})$ was determined by the ratio between the total farm crop production and the total area planted with crops in a given farm. Farm-produced feed ( $\mathrm{kg}$ of DM) was the total farm crop production plus the initial inventory minus the ending inventory minus crops sold. All feed fed to the herd (forage and concentrates, $\mathrm{kg}$ of DM) included farm-produced feed plus purchased feed and storage and handling losses. The percentage of homegrown feed was the ratio between farm-produced feed and all feed fed to the herd. The feed nutrient use efficiency was defined as the total nutrients sold in milk plus animals, divided by all nutrients fed to the herd. The whole-farm nutrient use efficiency was defined as the ratio between total nutrient exports and total nutrient imports. For each farm, a gross estimation of the annual DM intake of the herd was calculated by considering the animal units per farm and a daily DMI of $3 \%$ of the BW (NRC, 2001).

\section{Rainfall and Commodity Prices}

The weather conditions were slightly wetter than the average of the previous $30 \mathrm{yr}(1,013 \mathrm{~mm} / \mathrm{yr})$ across NY, with the exception of 2009 and 2012 (Table 1). The price paid by farmers for different feeds increased at an annual rate of $\$ 22$ to $\$ 38 / \mathrm{Mg}$ per year, depending on the feedstuff, with a sharp increase in 2008 (Table 1). A similar trend was observed for the price of fertilizers, which increased by $\$ 40$ to $\$ 52 / \mathrm{Mg}$ per year over the study period. The price paid to farmers for wheat, corn, and soybeans increased by $\$ 21$ to $\$ 35 / \mathrm{Mg}$ per year, whereas baled hay remained constant in price over time (Table 1). Milk price fluctuated over time; milk prices were lowest in 2006 and 2009 and highest in 2007, 2011, and 2012 (Table 1). Prices were obtained from NYSASS (2013), except canola prices, which were obtained from USDA-ERS (2014). 
NITROGEN AND PHOSPHORUS TRENDS

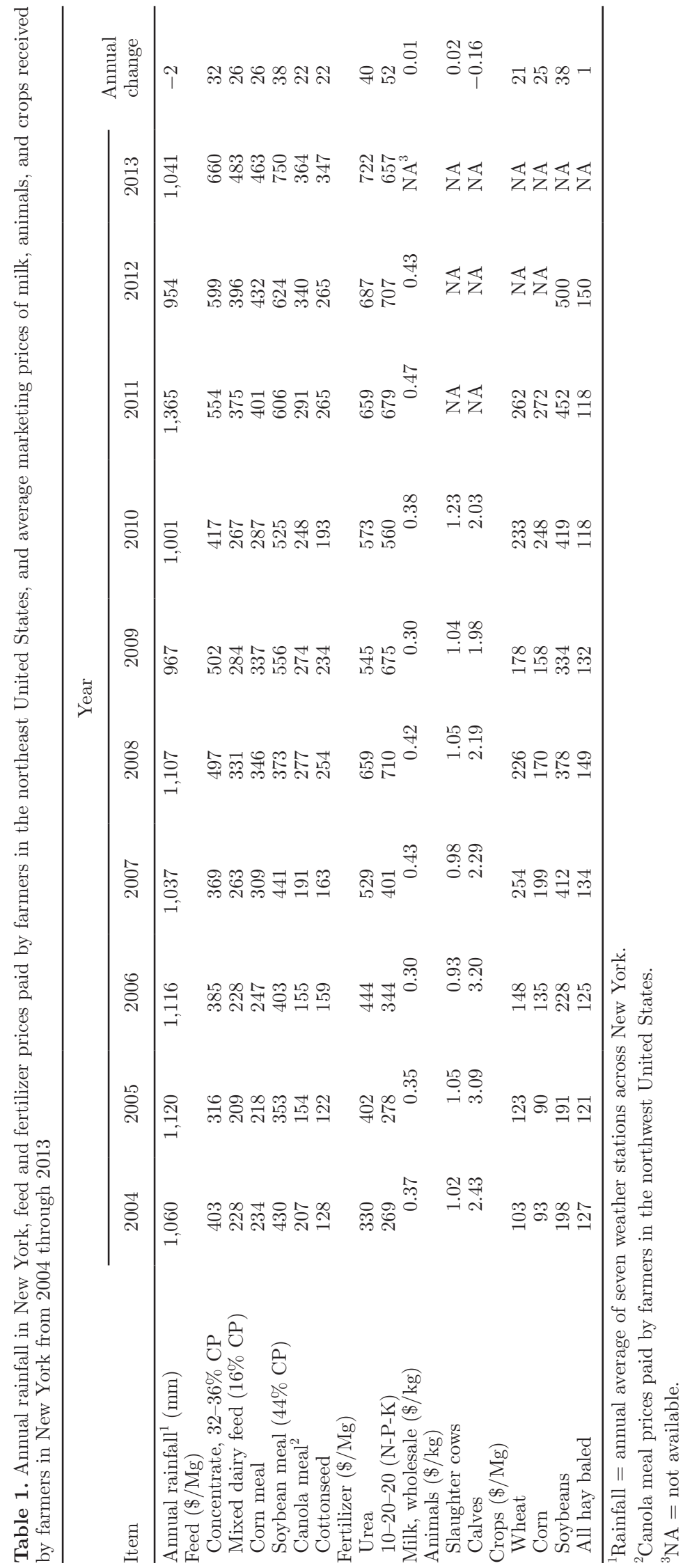




\section{Statistical Analyses}

For each of the 27 farms, NMB were regressed against the year to evaluate the trends in NMB over time, with positive and negative slopes indicating increases and decreases in NMB over time, respectively. The first and the last $2 \mathrm{NMB}$ per hectare of each farm were plotted against the milk production per hectare to determine if farms were moving toward more optimal NMB levels over time (directionally correct changes). Key indicators to predict areas for improvement were evaluated by regressing NMB per hectare (without manure exports) on total nutrient imports per hectare, feed imports per hectare, percentage of homegrown feed and nutrients fed, animal density, and feed use efficiency. For each of the 4 case study farms, simple linear regressions were performed with NMB per hectare as the dependent variable and the different farm characteristics, types of imports, and types of exports as independent variables. Analyses were performed with SAS 9.3 (SAS Institute, 2013).

\section{RESULTS AND DISCUSSION}

\section{Trends of NMB for the 27 Farms}

Most of the farms decreased the NMB per hectare over time ( $70 \%$ for N1, $74 \%$ for N2, and $67 \%$ for P; Figure 3). The annual change in NMB per hectare ranged from -30 to $17 \mathrm{~kg}$ of $\mathrm{N} /$ ha per year for $\mathrm{N} 1$, from -34 to $18 \mathrm{~kg}$ of $\mathrm{N} /$ ha per year for $\mathrm{N} 2$, and from -6 to $2 \mathrm{~kg}$ of $\mathrm{P} /$ ha per year. Similarly, most of the farms decreased the NMB per megagram of milk over time $(67 \%$ for $\mathrm{N} 1,63 \%$ for $\mathrm{N} 2$, and $63 \%$ for $\mathrm{P}$ ). The annual change in NMB per megagram of milk ranged from -3.8 to 1.6 $\mathrm{kg}$ of $\mathrm{N} / \mathrm{Mg}$ per year for $\mathrm{N} 1$, from -3.9 to $1.2 \mathrm{~kg}$ of N/ $\mathrm{Mg}$ per year for $\mathrm{N} 2$, and from -0.62 to $0.34 \mathrm{~kg}$ of $\mathrm{P} / \mathrm{Mg}$ per year. In general, changes in $\mathrm{N} 1$ and $\mathrm{P}$ balances over time were directionally correct. The percentage of NMB that fell in the optimal operational zone increased over time, from 22 to $26 \%$ over the first 2 yr to 43 to $56 \%$ over the last $2 \mathrm{yr}$ of assessments (Figure 4).

\section{Case Study Farm 1}

Initial Mass Balances and Key Indicators. In the first 2 yr of the study, Farm 1 greatly exceeded the feasible NMB (Figure 5). At that time, Farm 1 had $2.48 \mathrm{AU} / \mathrm{ha}$ (Figure 1), imported $297 \mathrm{~kg}$ of N/ha (322 kg of N/ha including $\mathrm{N}_{2}$ fixation) and $38 \mathrm{~kg}$ of $\mathrm{P} /$ ha. Feed imports accounted for $247 \mathrm{~kg}$ of N/ha $(83 \%$ of the total N1 imports, $77 \%$ of the total N2 imports) and $32 \mathrm{~kg}$ of $\mathrm{P} / \mathrm{ha}$ ( $84 \%$ of the total $\mathrm{P}$ imports; Figure
6). The percentages of homegrown feed (\% of DM fed), homegrown $\mathrm{N}$ fed (\% of all $\mathrm{N}$ fed), and homegrown $\mathrm{P}$ fed (\% of all $\mathrm{P}$ fed) were 62,40 , and $44 \%$, respectively. The initial whole-farm nutrient use efficiencies were $26 \%$ for N1, $24 \%$ for N2, and $36 \%$ for P, and the initial feed nutrient use efficiencies were $19 \%$ for $\mathrm{N}$ and $24 \%$ for P (Figure 7).

Evolution of Mass Balances and Main Drivers for Change. Farm 1 reduced its NMB and operated close to or below the feasible NMB $\pm 10 \%$ over the last 6 yr of the study (Figure 5). Changes in its $\mathrm{N}$ and $\mathrm{P}$ balances were primarily driven by changes in feed imports, whereas changes in $\mathrm{P}$ balances were also correlated with changes in fertilizer $\mathrm{P}$ imports (Table 2). The NMB per hectare were negatively correlated with the number of tillable hectares, the percentage of homegrown feed and nutrients, the concentration of $\mathrm{CP}$ in the homegrown feed, and the feed $\mathrm{P}$ use efficiency, and were positively correlated with the concentration of $\mathrm{P}$ in all feed and in the purchased feed (Table 3). Farm 1 increased the whole-farm nutrient use efficiency (from 26 to $44 \%$ for N1, from 24 to $38 \%$ for N2, and from 36 to $81 \%$ for $\mathrm{P}$ ) and the feed nutrient use efficiency (from 19 to $23 \%$ for N, and from 24 to $32 \%$ for P; Figure 7 ).

Specific Management Changes. The farmer reduced the amounts of $\mathrm{N}$ and $\mathrm{P}$ imported through feed by $121 \mathrm{~kg}$ of $\mathrm{N} / \mathrm{ha}(\sim 12 \mathrm{~kg}$ of $\mathrm{N} /$ ha per year, $49 \%$ reduction) and by $16 \mathrm{~kg}$ of $\mathrm{P} / \mathrm{ha}(\sim 1.6 \mathrm{~kg}$ of $\mathrm{P} / \mathrm{ha}$ per year, $50 \%$ reduction) between the first 2 and the last $2 \mathrm{yr}$ in the study (Figure 6A, B), primarily due to a reduction in purchased feed (Figure $6 \mathrm{C}, \mathrm{D}$ ) and reduction in the concentration of nutrients in the purchased feed [from 25.9 to $20.0 \%$ of $\mathrm{CP}$ ( $23 \%$ reduction) and from 0.53 to $0.41 \%$ of $\mathrm{P}$ ( $23 \%$ reduction); Figure $6 \mathrm{E}$, F]. Over time, Farm 1 discontinued the purchase of canola meal $(40.9 \% \mathrm{CP}, 1.20 \% \mathrm{P})$ and reduced the purchased amount of cornmeal $(9.0 \% \mathrm{CP}, 0.30 \% \mathrm{P})$, minerals $(30.6 \% \mathrm{CP}, 0.08 \% \mathrm{P})$, soybean meal $(52.8 \%$ $\mathrm{CP}, 0.71 \% \mathrm{P})$, and ground wheat $(14.2 \% \mathrm{CP}, 0.42 \%$ $\mathrm{P})$. These ration ingredients were substituted by AminoMax Pro (46.5\% CP, $1.01 \%$ P; Afgritech LLC, Watertown, NY), high-moisture ear corn $(9.0 \% \mathrm{CP}, 0.27 \%$ $\mathrm{P})$, steam-flaked corn $(7.3 \% \mathrm{CP}, 0.19 \% \mathrm{P})$, and straw $(4.8 \% \mathrm{CP}, 0.10 \% \mathrm{P})$. In addition, the farmer gradually reduced the concentration of nutrients in a protein mix, from $46.5 \% \mathrm{CP}$ and $0.38 \% \mathrm{P}$ to an average of $23.0 \%$ of $\mathrm{CP}$ and $0.14 \%$ of $\mathrm{P}$ over the last $2 \mathrm{yr}$. As a result of these changes, the concentration of $\mathrm{CP}$ and $\mathrm{P}$ in all feed (whole herd) decreased from $16.5 \% \mathrm{CP}$ and $0.36 \%$ $\mathrm{P}$ in the first $2 \mathrm{yr}$ to $15.1 \% \mathrm{CP}$ and $0.33 \% \mathrm{P}$ in the last 2 yr. These numbers include handling and storage losses of homegrown and purchased feed, thus nutrient concentrations at the cow level will differ. 

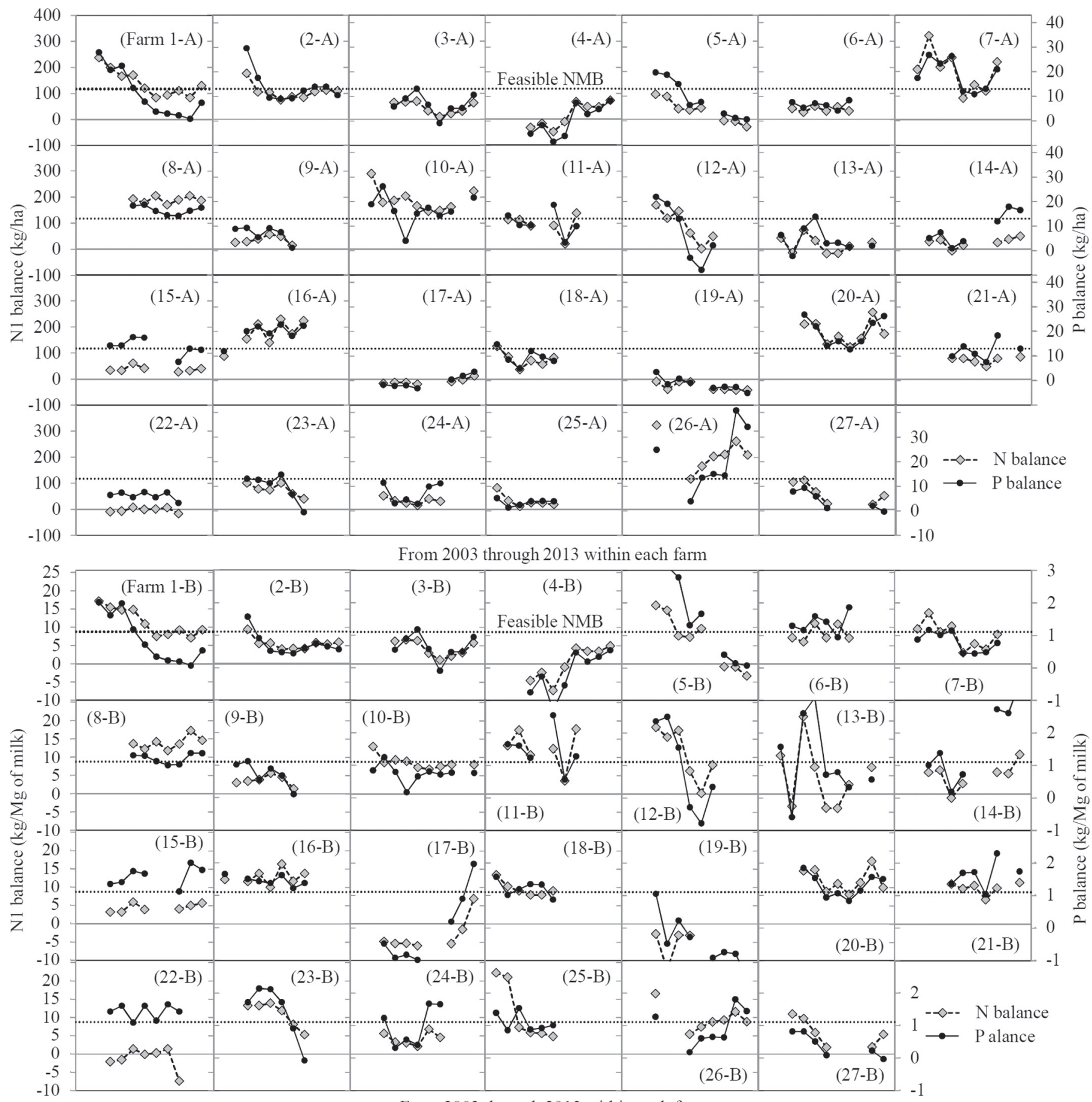

From 2003 through 2013 within each farm

Figure 3. Nitrogen mass balances without $\mathrm{N}_{2}$ fixation (gray diamonds, left y-axis) and $\mathrm{P}$ mass balances (black diamonds, right y-axis) per hectare (top figures) and per megagram of milk (bottom figures) for 27 dairy farms in New York over the study period. The dashed lines indicate the feasible mass balances per hectare $(<118 \mathrm{~kg}$ of $\mathrm{N} / \mathrm{ha}$ and $<13 \mathrm{~kg}$ of $\mathrm{P} / \mathrm{ha})$ and per megagram of milk $(<8.8 \mathrm{~kg}$ of N/Mg and $1.1 \mathrm{~kg}$ of $\mathrm{P} /$ $\mathrm{Mg}$ ) suggested for New York based on Cela et al. (2014).

The farmer also reduced $\mathrm{P}$ fertilizer imports over time, from $6 \mathrm{~kg}$ of $\mathrm{P} / \mathrm{ha}$ in 2004 and 2005 to $1 \mathrm{~kg}$ of $\mathrm{P} / \mathrm{ha}$ in 2011 and 2012. The farmer changed the corn starter blend from 20-20-0 $\left(\mathrm{N}^{-} \mathrm{P}_{2} \mathrm{O}_{5}-\mathrm{K}_{2} \mathrm{O}\right)$ in the beginning of the study (2004-2007) to 21-11-0 (in 2008-2009), and finally to $18-8-0$ and 5-0-8 after 2010, reflecting farm research that showed no need for $\mathrm{P}$ in the starter for soil testing high or very high in $\mathrm{P}$ (Ketterings et al., 
2005; Ketterings and Czymmek, 2012). As previously mentioned, the farmer built a 12.1-million-liter manure storage facility in 2006, which allowed him to store manure for 6 mo and make better use of manure nutrients, reducing the need for mineral fertilizer. Farm 1 did not export crops over the study period, but manure was exported from 2009 through 2013, representing 1 to $19 \%$ of total $\mathrm{N}$ and $\mathrm{P}$ exports, depending on the nutrient and year.

\section{Case Study Farm 2}

Initial Mass Balances and Key Indicators. In 2005, Farm 2 greatly exceeded the feasible NMB per hectare and the $\mathrm{P}$ balance per megagram of milk (Figure 5). At that time, Farm 2 had 3.0 AU/ha (Figure 1), imported a total of $312 \mathrm{~kg}$ of $\mathrm{N} / \mathrm{ha}(365 \mathrm{~kg}$ of $\mathrm{N} /$ ha including $\mathrm{N}_{2}$ fixation), and a total of $54 \mathrm{~kg}$ of $\mathrm{P} /$ ha. Feed imports accounted for $284 \mathrm{~kg}$ of $\mathrm{N} / \mathrm{ha}$
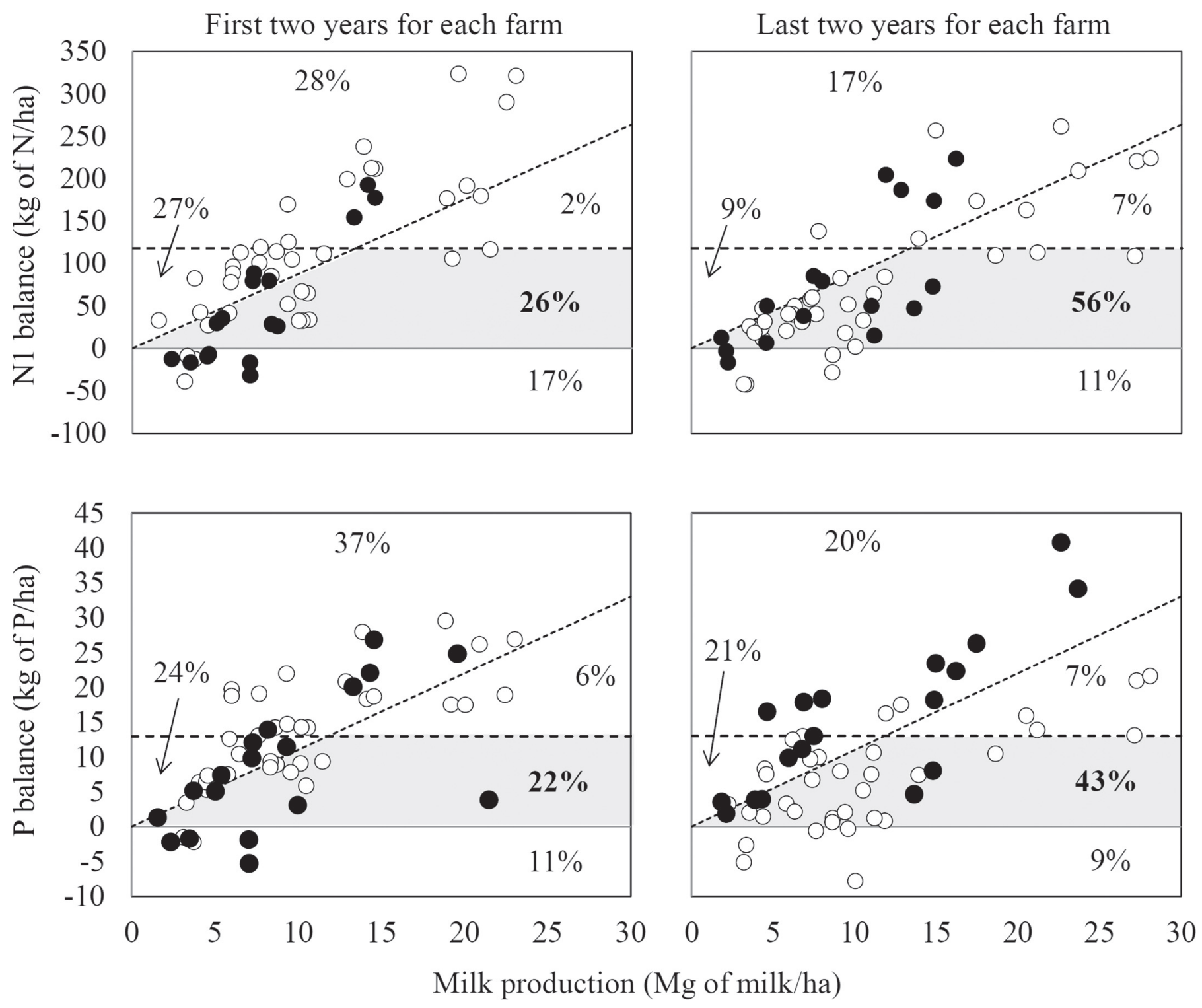

○ Reduced balances per ha

- Increased balances per ha

Figure 4. Nitrogen (without $\mathrm{N}_{2}$ fixation, $\mathrm{kg}$ of $\mathrm{N} / \mathrm{ha}$ ) and $\mathrm{P}$ mass balances ( $\mathrm{kg}$ of $\mathrm{P} / \mathrm{ha}$ ) as a function of the milk production per hectare for 27 New York dairy farms. The dashed horizontal line indicates the feasible nutrient mass balance (NMB) per hectare suggested for New York $(<118 \mathrm{~kg}$ of $\mathrm{N} / \mathrm{ha},<13 \mathrm{~kg}$ of $\mathrm{P} / \mathrm{ha})$. The dashed diagonal line indicates the feasible NMB per megagram of milk suggested for New York $(<8.8$ $\mathrm{kg}$ of $\mathrm{N} / \mathrm{Mg}$ of milk, and $<1.1 \mathrm{~kg}$ of $\mathrm{P} / \mathrm{Mg}$ of milk). Farms in the gray area operate with feasible NMB per hectare and per megagram of milk. 


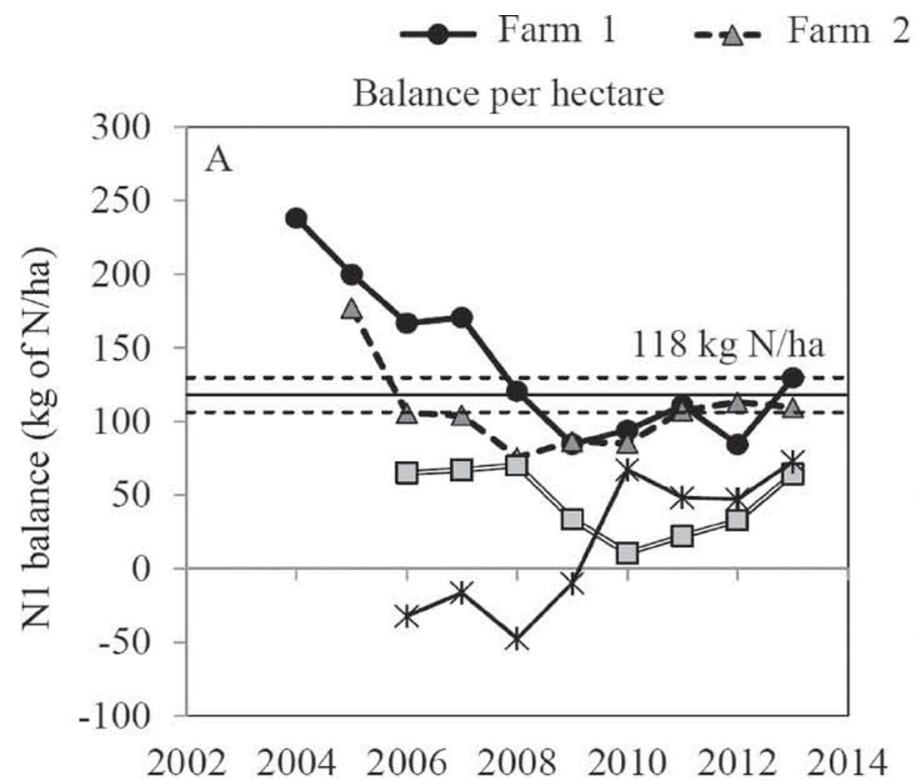

$\rightarrow$ * Farm $3 \stackrel{\square}{\square}$ Farm 4
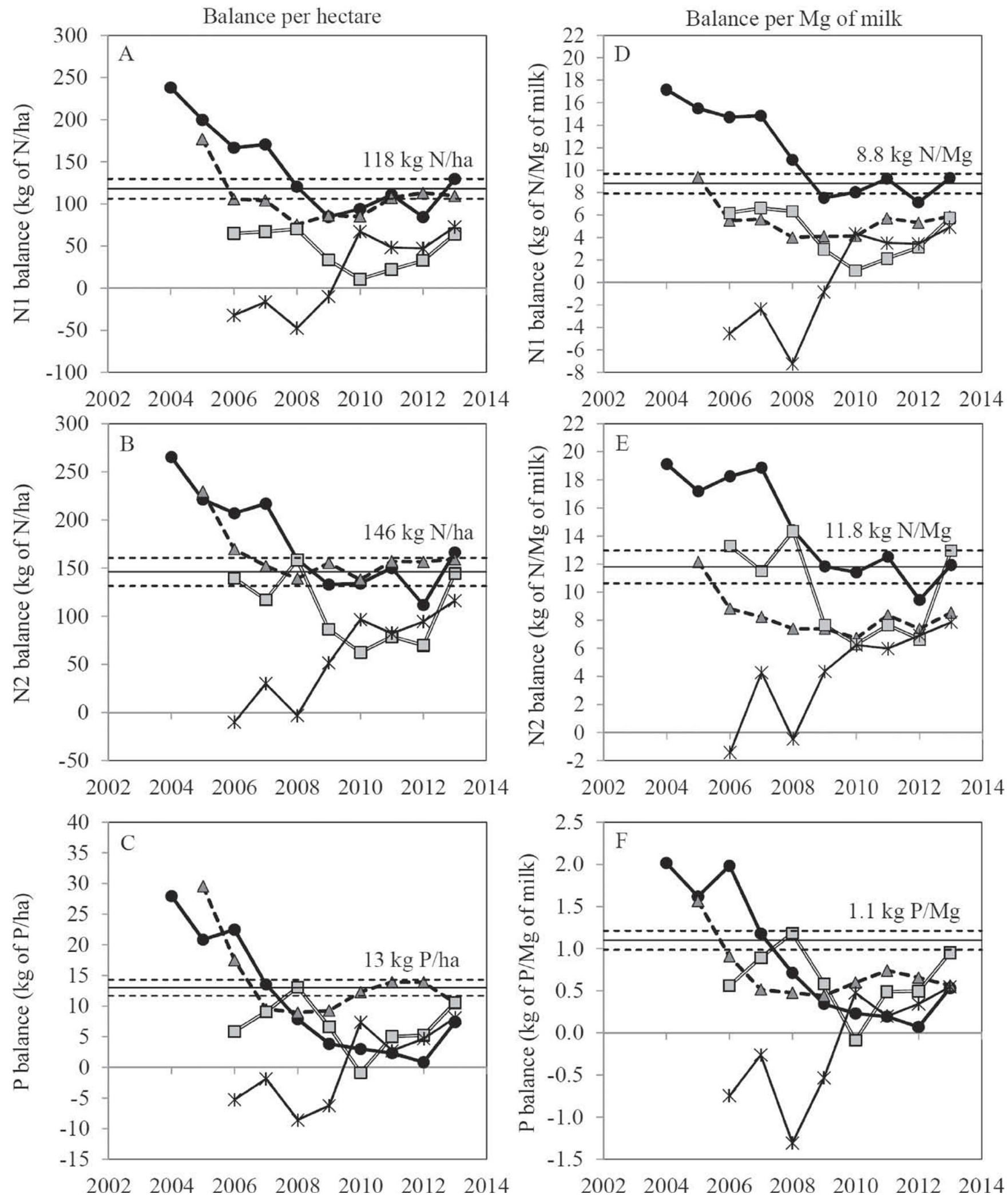

Figure 5. Nitrogen and P mass balances per hectare (A, B, C) and per megagram of milk (D, E, F), for 4 New York case study dairy farms. The horizontal lines show the feasible nutrient mass balance suggested for New York $\pm 10 \%$ based on Cela et al. (2014). 

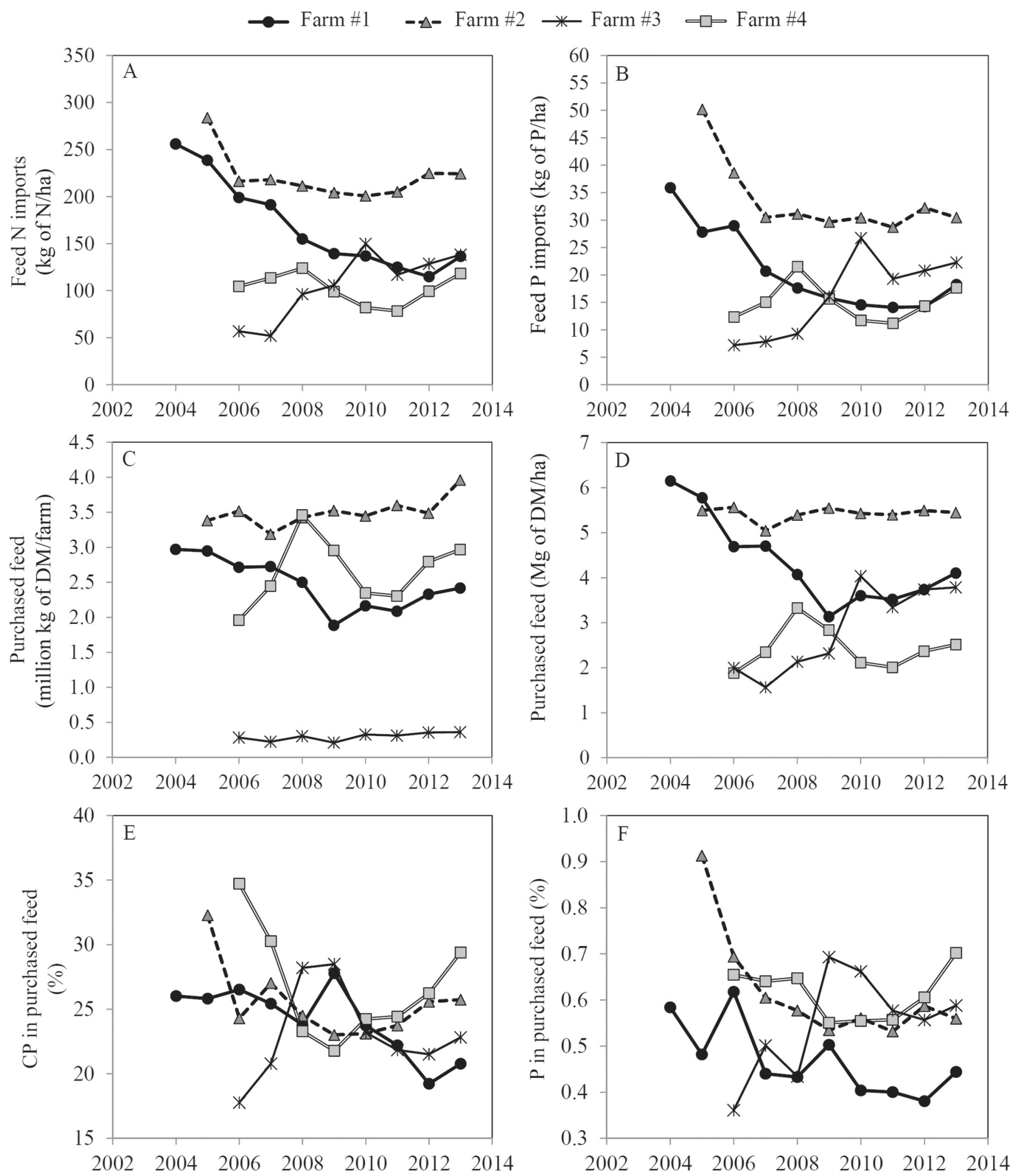

Figure 6. Evolution of the (A, B) feed $\mathrm{N}$ and $\mathrm{P}$ imports per tillable hectare, $(\mathrm{C})$ purchased feed per farm, (D) purchased feed per hectare, and $(\mathrm{E}, \mathrm{F})$ concentration of $\mathrm{CP}$ and $\mathrm{P}$ in the purchased feed, for 4 New York case study dairy farms. 
Table 2. Linear regressions with $\mathrm{N}_{2}$ (with $\mathrm{N}_{2}$ fixation, $\mathrm{kg}$ of $\mathrm{N} / \mathrm{ha}$ ) and $\mathrm{P}$ balances $(\mathrm{kg}$ of $\mathrm{P} / \mathrm{ha}$ ) as dependent variables and different types of nutrient imports and exports as independent variables, for 4 case study farms ${ }^{1}$

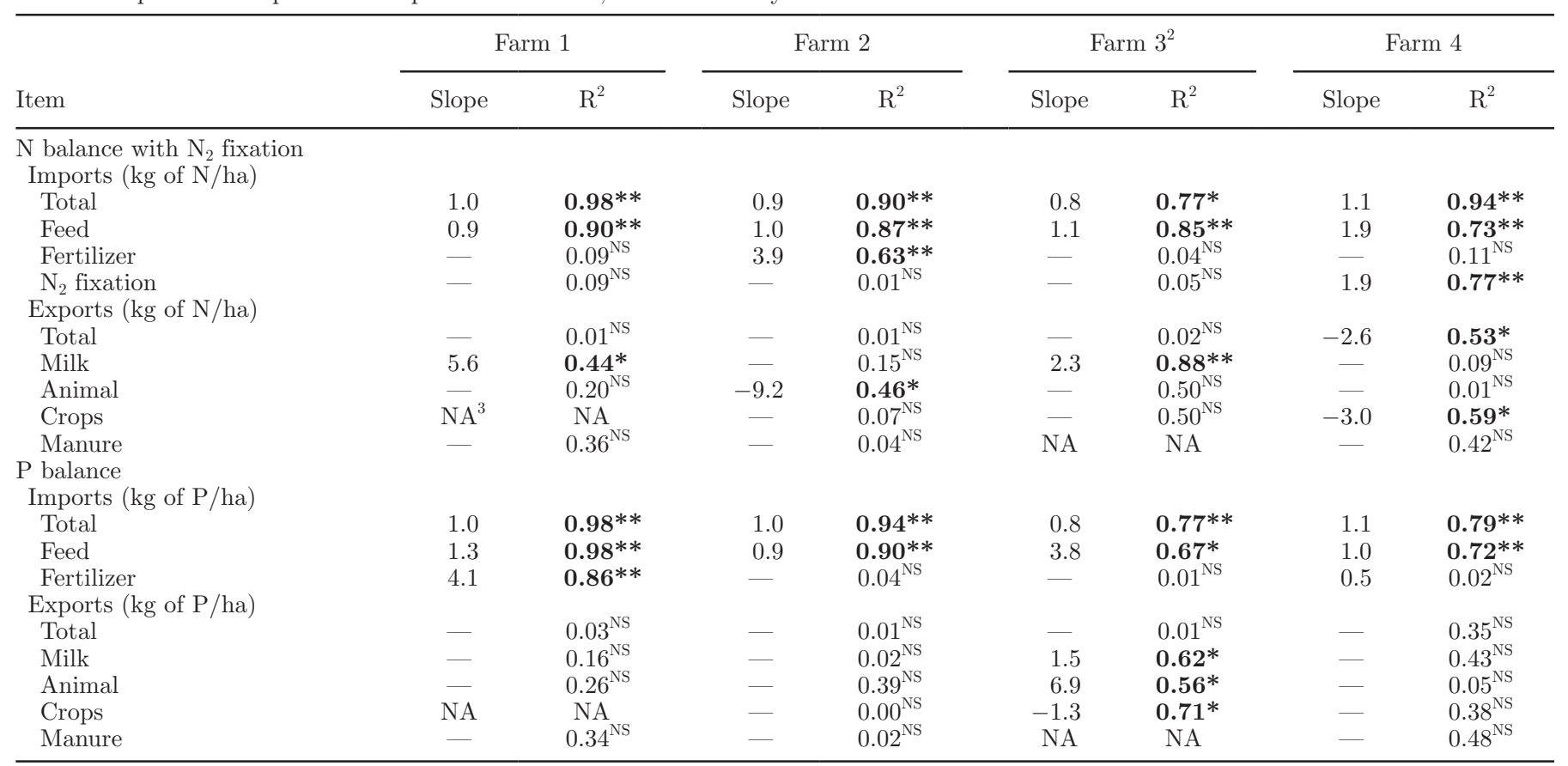

${ }^{1}$ Bold values highlight variables that are significant $(\alpha=0.05)$.

${ }^{2}$ In Farm 3, 2008 was not considered in the regressions because of the very large crop exports.

${ }^{3} \mathrm{NA}=$ not available.

${ }^{*} P<0.05 ;{ }^{* *} P<0.01, \mathrm{NS}=$ not significant.
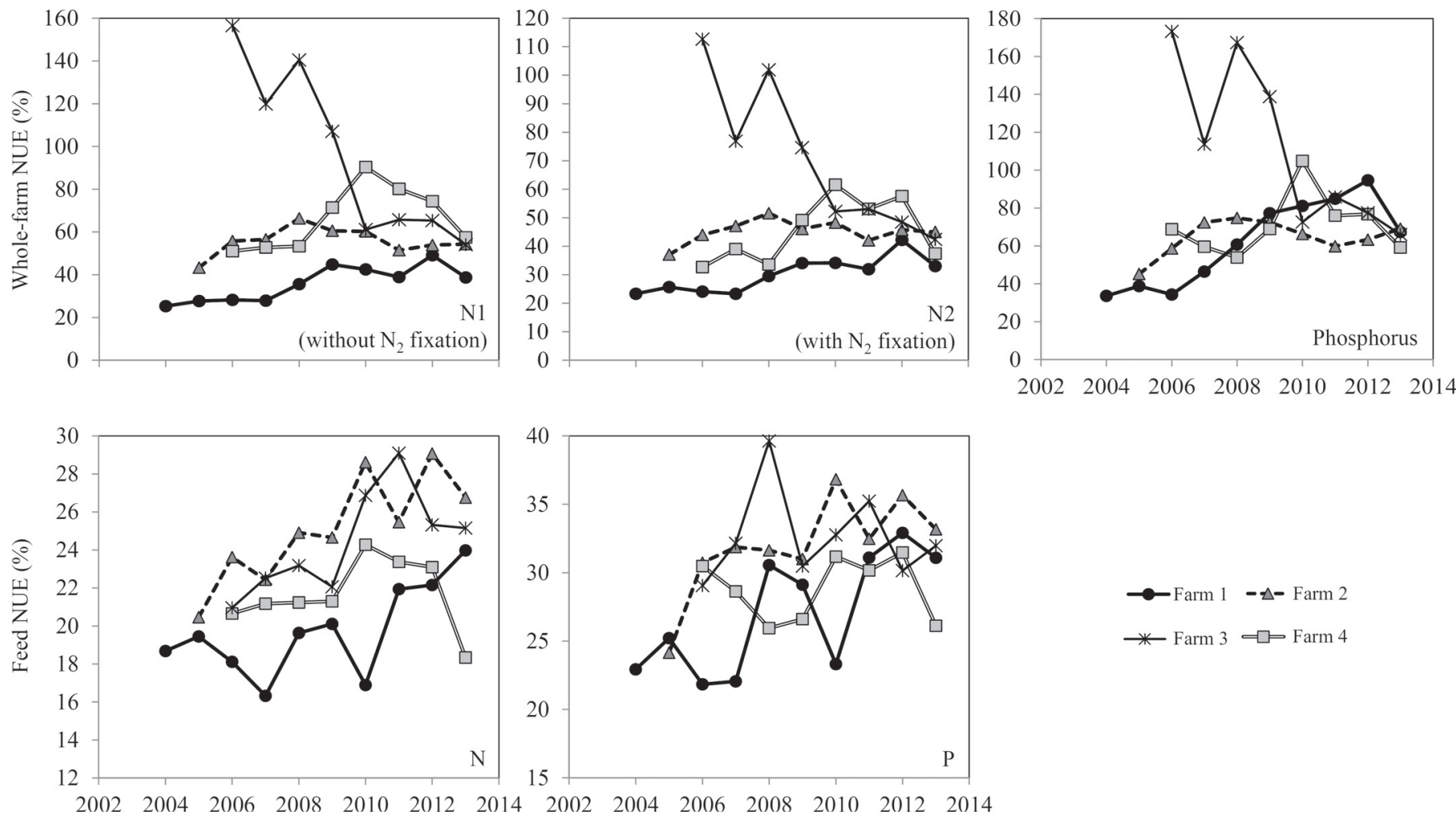

Figure 7. Evolution of whole-farm and feed nutrient use efficiencies (NUE) for 4 New York case study dairy farms over the study period. 
(91\% of the total N1 imports, $78 \%$ of the total N2 imports) and 50 of $\mathrm{kg} \mathrm{P} /$ ha $(93 \%$ of the total $\mathrm{P}$ imports; Figure 6). The percentages of homegrown DM, $\mathrm{N}$, and $\mathrm{P}$ fed were 67,44 , and $39 \%$, respectively. The initial whole-farm nutrient use efficiencies were $43 \%$ for $\mathrm{N} 1,37 \%$ for $\mathrm{N} 2$, and $45 \%$ for $\mathrm{P}$, and the initial feed nutrient use efficiencies were $20 \%$ for $\mathrm{N}$ and $24 \%$ for $\mathrm{P}$ (Figure 7).

Evolution of Mass Balances and Main Drivers for Change. Farm 2 reduced its NMB in the second year of the study and operated below the feasible NMB $\pm 10 \%$ during the last 7 yr (Figure 5). Changes in its NMB per hectare were primarily driven by changes in its feed nutrient imports, whereas changes in the $\mathrm{N}$ balances per hectare were also correlated with changes in $\mathrm{N}$ fertilizer imports (Table 2). Mass balances per hectare were negatively correlated with the percentage of homegrown nutrients and with feed use efficiency, and positively correlated with the concentrations of $\mathrm{CP}$ and $\mathrm{P}$ in all feed and in purchased feed (Table 3). Farm 2 increased its whole-farm nutrient use efficiencies (from 43 to $54 \%$ for N1, from 37 to $45 \%$ for N2, and from 45 to $66 \%$ for $\mathrm{P}$ ) and its feed nutrient use efficiencies over time (from 20 to $28 \%$ for N, and from 24 to $34 \%$ for P; Figure 7).
Specific Management Changes. At this farm, the amount of $\mathrm{N}$ and $\mathrm{P}$ purchased via feed was reduced by $60 \mathrm{~kg}$ of $\mathrm{N} / \mathrm{ha}(21 \%$ reduction) and by $19 \mathrm{~kg}$ of $\mathrm{P} / \mathrm{ha}$ (38\% reduction; Figure 6A, B). Most of this reduction was obtained in the first 2 yr by reducing the concentration of $\mathrm{CP}$ and $\mathrm{P}$ in the purchased feed (Figure $6 \mathrm{E}$, $\mathrm{F}$ ); the amounts of purchased feed did not change over time (Figure 6C, D). The percentages of $\mathrm{CP}$ and $\mathrm{P}$ in purchased feed decreased from $32.3 \% \mathrm{CP}$ and $0.91 \%$ $\mathrm{P}$ in 2005 to an average of $25.6 \% \mathrm{CP}$ and $0.57 \% \mathrm{P}$ over the last $2 \mathrm{yr}$ of the study (Figure $6 \mathrm{E}, \mathrm{F}$ ). Over time, the farmer discontinued the purchase of soybean meal $(52.8 \% \mathrm{CP}, 0.71 \% \mathrm{P})$, cottonseed $(23 \% \mathrm{CP}, 0.58 \%$ $\mathrm{P})$, oat hulls $(3.6 \% \mathrm{CP}, 0.70 \% \mathrm{P})$, and hay $(19.5 \%$ $\mathrm{CP}, 0.32 \% \mathrm{P})$, and reduced the purchase of minerals $(0 \% \mathrm{CP}, 15 \% \mathrm{P})$. These ingredients were replaced by AminoMax (48\% CP, $0.68 \%$ P; Afgritech LLC) and by higher purchases of cornmeal $(9.0 \% \mathrm{CP}, 0.30 \% \mathrm{P})$, premix $(40.0 \% \mathrm{CP}, 1.71 \% \mathrm{P})$, and straw $(4 \% \mathrm{CP}, 0.64 \%$ $\mathrm{P})$. In addition, Farm 2 greatly reduced the concentration of $\mathrm{P}$ in the premix, from $1.71 \%$ in 2005 to $0.68 \%$ of $\mathrm{P}$ from 2007 onwards. These changes resulted in a reduction of the concentration of $\mathrm{CP}$ and $\mathrm{P}$ in all feed, from $17.8 \% \mathrm{CP}$ and $0.44 \% \mathrm{P}$ in the first $2 \mathrm{yr}$ to $16.5 \%$ $\mathrm{CP}$ and $0.39 \% \mathrm{P}$ in the last $2 \mathrm{yr}$.

Table 3. Linear regressions with $\mathrm{N}_{2}$ (with $\mathrm{N}_{2}$ fixation, $\mathrm{kg}$ of $\mathrm{N} / \mathrm{ha}$ ) and $\mathrm{P}$ balances $(\mathrm{kg}$ of $\mathrm{P} / \mathrm{ha}$ ) as dependent variables and various farm characteristics and management practices as independent variables, for 4 case study farms

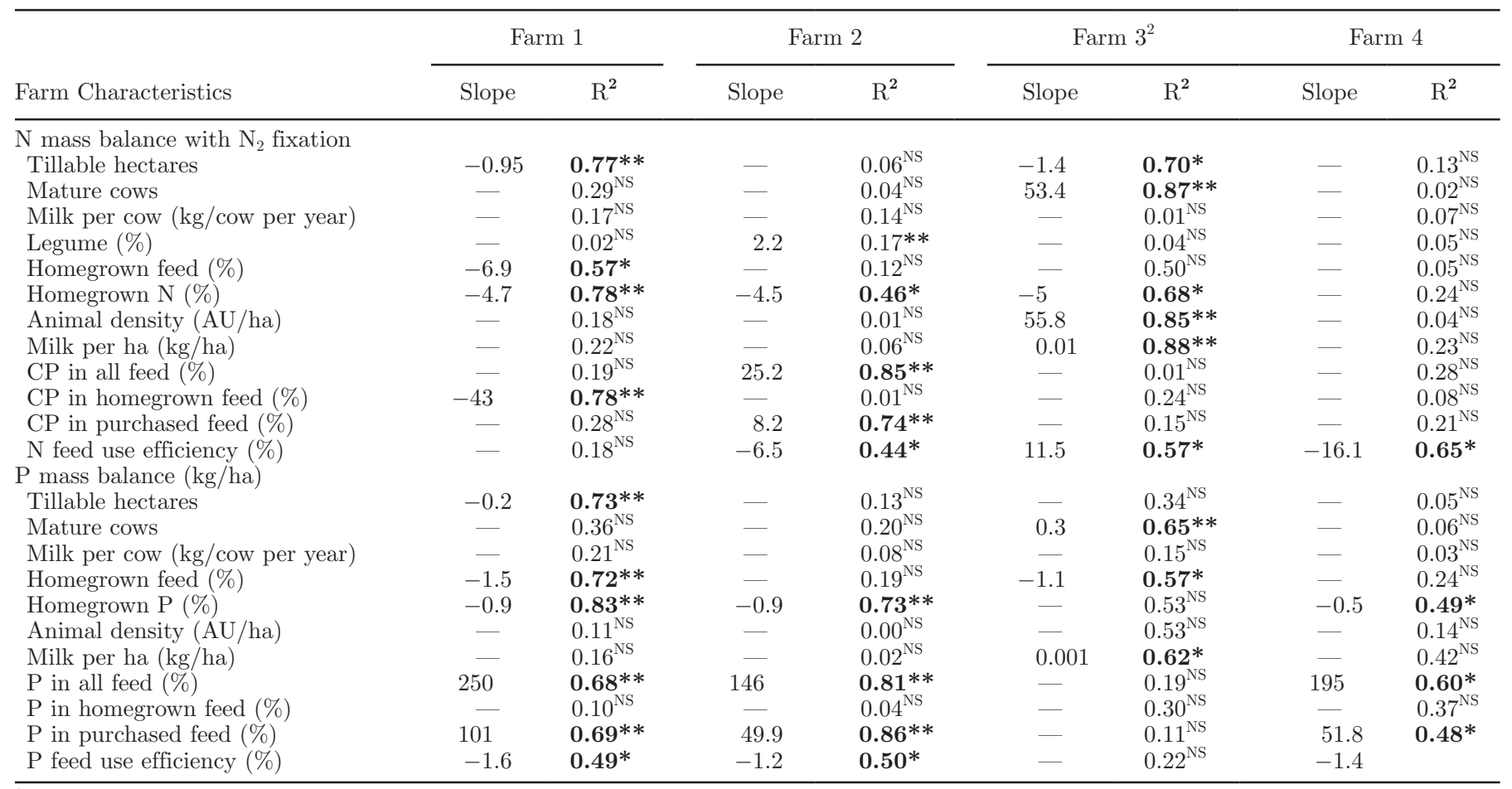

${ }^{1}$ Bold values highlight variables that are significant $(\alpha=0.05)$.

${ }^{2}$ In Farm 3, 2008 was not considered in the regressions because of the large crop exports.

${ }^{*} P<0.05 ; * * P 0.01, \mathrm{~ns}=$ not significant. 
The farmer also reduced $\mathrm{N}$ fertilizer purchases over time, from $20 \mathrm{~kg}$ of $\mathrm{N} / \mathrm{ha}$ in 2005 to an average of $4 \mathrm{~kg}$ of $\mathrm{N} /$ ha in the last $2 \mathrm{yr}$ of the study. Nitrogen starter use for corn was discontinued based on the results of on-farm trials that showed no crop decline with omission of starter $\mathrm{N}$ fertilizer (Ketterings, 2013; Ketterings et al., 2013). In this farm, $100 \%$ of the tillable acres received manure every year, allowing the farmer to operate fields with a low amount of purchased fertilizers as compared with other dairies. Farm 2 exported crops every year ( 1 to $11 \%$ of total $\mathrm{N}$ and $\mathrm{P}$ exports) and manure from 2005 through 2009 (7-8 to $21-24 \%$ of total $\mathrm{N}$ and $\mathrm{P}$ exports).

\section{Case Study Farm 3}

Initial Mass Balances and Key Indicators. In the first 2 yr, Farm 3 operated with negative N1 and P balances per hectare, whereas N2 balances (including $\mathrm{N}_{2}$ fixation) were close to zero or positive (Figure 5). At that time, Farm 3 had a low animal density (1.16 $\mathrm{AU} / \mathrm{ha}$ ) and imported $70 \mathrm{~kg}$ of N/ha (104 kg of N/ha including $\mathrm{N}_{2}$ fixation) and $10 \mathrm{~kg}$ of $\mathrm{P} /$ ha. Feed imports accounted for $54 \mathrm{~kg}$ of N/ha (77\% of total N1 imports, $52 \%$ of total $\mathrm{N} 2$ imports) and $8 \mathrm{~kg}$ of $\mathrm{P} / \mathrm{ha}$ ( $80 \%$ of the total $\mathrm{P}$ imports). The percentages of homegrown feed, $\mathrm{N}$ and $\mathrm{P}$ fed were 79,72 , and $71 \%$, respectively, feed nutrient use efficiencies were $22 \%$ for $\mathrm{N}$ and $31 \%$ for $\mathrm{P}$, and the whole-farm nutrient use efficiencies were $138 \%$ for N1, 95\% for N2 and 143\% for P (efficiencies higher than $100 \%$ reflect exports exceeding imports) (Figure 7).

Evolution of Mass Balances and Main Drivers for Change. Farm 3 greatly increased NMB over time and operated with positive NMB during the last $4 \mathrm{yr}$ of assessments (Figure 5). The increases in $\mathrm{N}$ and $\mathrm{P}$ balances per hectare over time were primarily driven by increases in feed $\mathrm{N}$ and $\mathrm{P}$ purchases and by reductions in crop exports (Table 2). Farm 3 reduced crop sales and increased $\mathrm{N}$ and $\mathrm{P}$ purchases via feed (Figure 1) to compensate for a $33 \%$ reduction in the land base due to loss of rented land and a $37 \%$ increase in the herd size after the installation of 2 milking robots in 2009. Mass balances were negatively correlated with the number of tillable hectares, the percentage of homegrown feed and homegrown $\mathrm{N}$, and were positively correlated with the number of mature cows, the animal density, and the milk production per hectare (Table 3). Farm 3 increased feed $\mathrm{N}$ use efficiency over time (from 22 to $25 \%$ ), maintained feed $\mathrm{P}$ use efficiency at $31 \%$, and decreased whole-farm nutrient use efficiencies below 100 (from 138 to $60 \%$ for N1, from 95 to $45 \%$ for N2, and from 143 to $72 \%$ for P), as inputs started to exceed exports (Figure 7).
Specific Management Changes. The feed nutrient imports increased over time by $79 \mathrm{~kg}$ of $\mathrm{N} / \mathrm{ha}$ ( $246 \%$ increase, $\sim 10 \mathrm{~kg}$ of $\mathrm{N} /$ ha per year) and by 14 $\mathrm{kg}$ of $\mathrm{P} / \mathrm{ha}(275 \%$ increase, $\sim 1.8 \mathrm{~kg}$ of $\mathrm{P} /$ ha per year; Figure $6 \mathrm{~A}, \mathrm{~B}$ ). The concentrations of protein and $\mathrm{P}$ in the purchased feed were increased from 19.3 to $22.2 \%$ $\mathrm{CP}$ in the initial $2 \mathrm{yr}$ and from 0.43 to $0.57 \% \mathrm{P}$ in the most recent years (Figure 6E). Over time, Farm 3 discontinued the purchase of soybean meal $(54 \% \mathrm{CP}$, $0.71 \% \mathrm{P})$ and reduced cornmeal use $(9.8 \% \mathrm{CP}, 0.30 \%$ $\mathrm{P})$. These ration ingredients were substituted by pellets (20\% CP, $0.59 \%$ P) and by an increase in the amounts of purchased protein mix ( $34 \% \mathrm{CP}, 0.58 \% \mathrm{P})$. Farm 3 exported corn silage, alfalfa haylage, and timothy when its animal density was $<1.3 \mathrm{AU} /$ ha, which contributed to their low (or negative) NMB in the beginning years. The farmer discontinued the export of crops in 2010 , when their animal density increased to $>2.6 \mathrm{AU} / \mathrm{ha}$, due to the increase in number of animals and loss of rented land. These changes resulted in an increase of the concentration of $\mathrm{CP}$ and $\mathrm{P}$ in all feed, from $14.8 \%$ $\mathrm{CP}$ and $0.32 \% \mathrm{P}$ in the first $2 \mathrm{yr}$ to $15.5 \% \mathrm{CP}$ and $0.37 \% \mathrm{P}$ in the last $2 \mathrm{yr}$.

\section{Case Study Farm 4}

Initial Mass Balances and Key Indicators. Farm 4 consistently had NMB per hectare and per megagram of milk below the feasible levels proposed for NY dairies, averaging 46, 107, and $7 \mathrm{~kg}$ /ha for $\mathrm{N} 1$, N2, and P, respectively (Figure 5). In the first $2 \mathrm{yr}$, Farm 4 had $1.95 \mathrm{AU} / \mathrm{ha}$, imported $138 \mathrm{~kg}$ of N/ha (200 $\mathrm{kg}$ of $\mathrm{N} / \mathrm{ha}$ including $\mathrm{N}_{2}$ fixation) and $21 \mathrm{~kg}$ of $\mathrm{P} / \mathrm{ha}$. Feed imports accounted for $109 \mathrm{~kg}$ of $\mathrm{N} / \mathrm{ha}$ (79\% of the total N1 imports, $55 \%$ of the total N2 imports) and $14 \mathrm{~kg}$ of $\mathrm{P} / \mathrm{ha}$ ( $67 \%$ of the total $\mathrm{P}$ imports). The percentages of homegrown $\mathrm{DM}, \mathrm{N}$, and $\mathrm{P}$ fed were 81 , 62 , and $65 \%$, respectively, the whole-farm nutrient use efficiencies were $52 \%$ for N1, $36 \%$ for $\mathrm{N} 2$ and $64 \%$ for $\mathrm{P}$, and the feed nutrient use efficiencies were $21 \%$ for $\mathrm{N}$ and $30 \%$ for $\mathrm{P}$ (Figure 7 ).

Evolution of Mass Balances and Main Drivers for Change. Nutrient mass balances of Farm 4 fluctuated over time without a clear trend (Figure 5). Fluctuations in its NMB per hectare were mainly driven by fluctuations in feed imports, crop exports, and $\mathrm{N}_{2}$ fixation of legumes (Table 2). Changes in NMB were negatively correlated with the percentage of homegrown $\mathrm{P}$ and with the feed nutrient use efficiencies, and positively correlated with the concentration of $\mathrm{P}$ in all feed and in the purchased feed (Table 3). Between the first $2 \mathrm{yr}$ and 2011 to 2012, Farm 4 increased whole-farm nutrient use efficiencies from 52 to $77 \%$ (N1), from 36 to $55 \%(\mathrm{~N} 2)$, and from 64 to $76 \%(\mathrm{P})$. Over the same 
period, Farm 4 increased feed $\mathrm{N}$ use efficiency from $21 \%$ to $23 \%$ and maintained feed $\mathrm{P}$ use efficiency at $30 \%$ (Figure 7). These efficiency indicators decreased in 2013 due to a reduction in milk production per cow caused by a discontinuation in the use of recombinant bovine somatotropin.

Specific Management Changes. Despite the fluctuations in feed imports, Farm 4 reduced the nutrient concentrations in purchased feed from 32.5 to $25.3 \%$ CP (22\% reduction), and from 0.65 to $0.58 \% \mathrm{P}(11 \%$ reduction), when comparing 2006 to 2007 with 2011 to 2012 (Figure 6E, F). Farm 4 discontinued the purchase of soybean meal $(52.8 \% \mathrm{CP}, 0.71 \% \mathrm{P})$ and cottonseed (23\% CP, $0.58 \%$ P) between 2009 and 2011 (consistent with the lowest NMB for those years), and increased the purchase of milk cow complete $(28.4 \% \mathrm{CP}, 0.70 \%$ $\mathrm{P})$ and gluten $(24 \% \mathrm{CP}, 0.95 \% \mathrm{P})$. Moreover, the farmer reduced the concentration of nutrients in the milk cow complete from 28.4 to $22.2 \% \mathrm{CP}$ and from 0.70 to $0.50 \%$ P when comparing 2006 to 2007 with 2010 to 2011, the years with their lowest NMB. In Farm 4, crop exports represented 9 to $37 \%$ of the total $\mathrm{N}$ exports (average $=25 \%$ ) and 9 to $40 \%$ of the total $\mathrm{P}$ exports (average $=23 \%$ ), depending on the year (Figure $8 \mathrm{E}, \mathrm{F}$ ). As a result of these changes, the concentration of protein in all feed decreased from $16.3 \% \mathrm{CP}$ in the first $2 \mathrm{yr}$ to $15.5 \%$ CP in 2011 to 2012 , whereas the concentration of $\mathrm{P}$ in all feed remained constant at $0.35 \% \mathrm{P}$.

\section{General Discussion}

The 27-farm database illustrates the potential for improving NMB in dairy farms over time. The management changes made were always farmer-driven. Farmers annually received a report comparing their NMB with those of their peers, without specific guidance on how to increase or decrease NMB. The reports did not include the feasible NMB (benchmarks were published in 2014), so they had no specific target to aim at.

The 4 case study farms show that it is possible for well-managed dairies to consistently operate with NMB below the feasible NMB suggested for NY, regardless of farm size and initial NMB. These farmers made the largest management changes in nutrient imports, whereas changes in exports were typically small (Table 2). Purchased feed was the main driver for change in NMB in all 4 case study farms. This highlights the importance of precision feed management as a mechanism to feed more closely to animal requirements leading to reduced $\mathrm{P}$ and $\mathrm{N}$ excretion and improve whole-farm NMB. Three of 4 farms reduced the concentration of $\mathrm{CP}$ and $\mathrm{P}$ in the purchased feed. Farms made these reductions while maintaining or increasing milk production, increasing the feed nutrient use efficiencies, and improving the whole-farm nutrient use efficiencies. Our results show that feeding strategies such as formulating diets closer to animal requirements and reducing protein and $\mathrm{P}$ in the diet can improve whole-farm NMB, consistent with findings of Kohn et al. (1997), Cerosaletti et al. (2004), and New York NRCS USDA (2005). The changes were typically accomplished by replacing concentrates such as soybean meal, cottonseed, or canola meal with blends with lower nutrient concentrations.

In addition to precision feeding, other options chosen by farms that resulted in improved NMB include fertilizer management, crop sales, manure exports, and increasing or reducing the farm's land base. In Farms 1 and 2, NMB were reduced by decreasing $\mathrm{N}$ and $\mathrm{P}$ fertilizer use (Table 2) without a negative effect on crop yields. Farms 3 and 4 showed that crop exports can effectively reduce NMB (Table 2, Figure $8 \mathrm{E}, \mathrm{F}$ ). For these farms, crop exports were feasible because they were producing most of the feed needed for their herd on the farm itself (Figure 2), which is more likely to happen in farms with relatively low animal densities $(<2.4 \mathrm{AU} / \mathrm{ha})$. Manure exports can also reduce NMB, especially in farms with high animal densities (2.4 AU/ ha or greater); 3 of the 4 case study farms exported manure during a part of the study (Figure 8G, H), and the amounts of manure exported increased with the animal density of the farm. Farms 1 and 3 also illustrate that changes in tillable hectares effect the NMB (Table 3). Although milk was typically the main nutrient export (Figure 8A, B), milk exports per hectare were either not correlated or positively correlated with NMB per hectare (Table 2), probably because milk production per hectare was closely linked to animal density across the 4 farms and over time $\left(\mathrm{R}^{2}=0.95, P<0.01\right)$.

\section{Key Indicators to Predict Areas for Improvement in Nutrient Mass Balances}

In Soberon et al. (2015), 6 key indicators were proposed for identifying the potential for improvement in NMB. Based on the 27-farm database, preliminary thresholds for 5 of these 6 key indicators were determined (Figure 9). Farms had a high likelihood of exceeding the feasible NMB per hectare if (1) total imports were $>210 \mathrm{~kg}$ of $\mathrm{N} / \mathrm{ha}$ and $>30 \mathrm{~kg}$ of $\mathrm{P} / \mathrm{ha}$; (2) feed imports were $>170 \mathrm{~kg}$ of $\mathrm{N} / \mathrm{ha}$ and $>27 \mathrm{~kg}$ of $\mathrm{P} /$ ha; (3) homegrown feed was $<62 \%$ for $\mathrm{N}$ and $\mathrm{P}$; (4) homegrown feed $\mathrm{N}$ and $\mathrm{P}$ was $<50 \%$; or (5) animal densities were $>2.8 \mathrm{AU} / \mathrm{ha}$. Similarly, farms have a low likelihood of exceeding the feasible NMB if (1) total imports were $<180 \mathrm{~kg}$ of $\mathrm{N} / \mathrm{ha}$ and $<25 \mathrm{~kg}$ of $\mathrm{P} / \mathrm{ha}$; (2) feed imports were $<140 \mathrm{~kg}$ of $\mathrm{N} / \mathrm{ha}$ and $<20 \mathrm{~kg}$ of $\mathrm{P} /$ ha; (3) homegrown feed was $>72 \%$ for $\mathrm{N}$ and $\mathrm{P}$; 

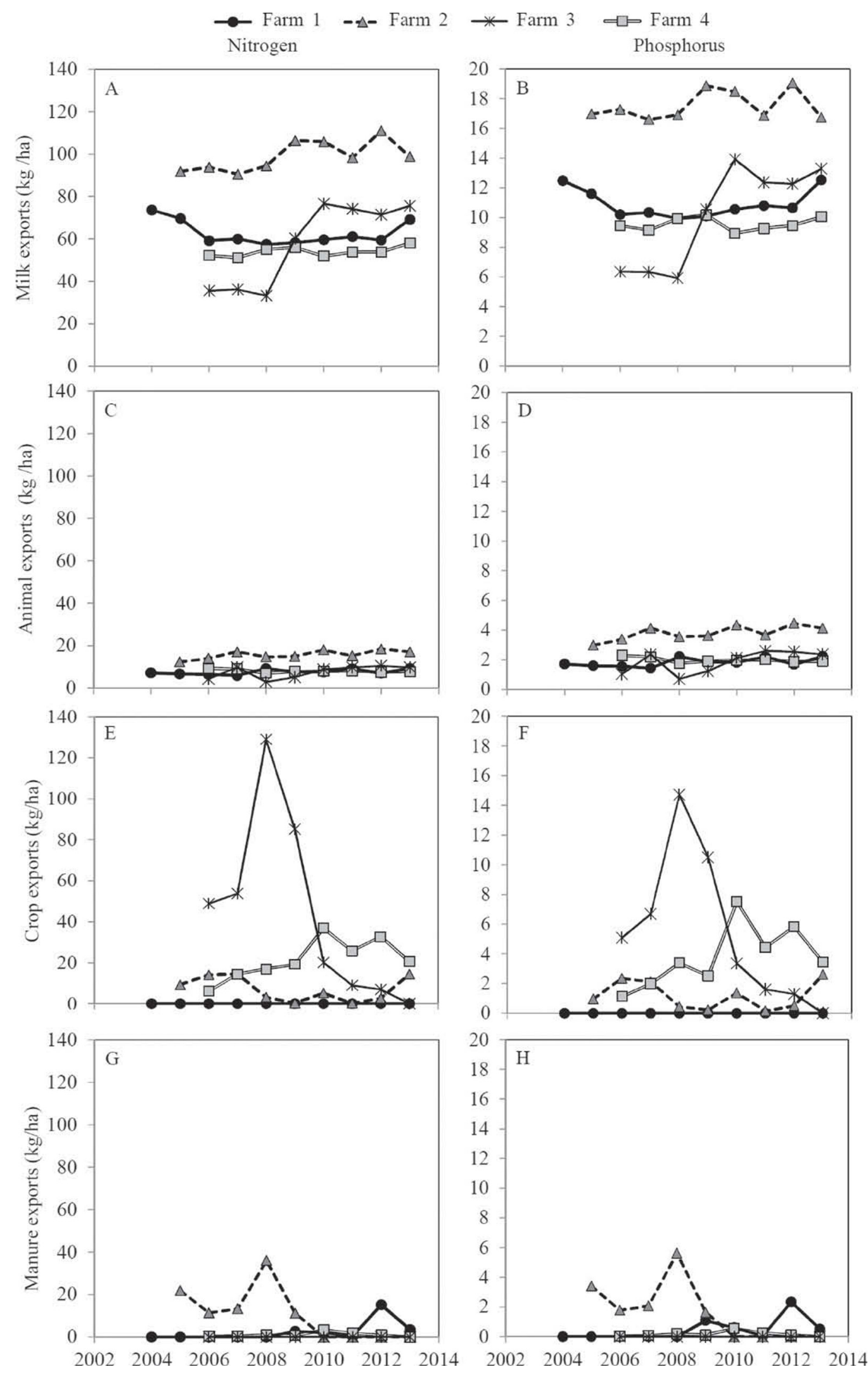

Figure 8. Evolution over time of the amounts of $\mathrm{N}$ and $\mathrm{P}$ exported from 4 New York case study dairy farms as milk (A and B), animals (C and $\mathrm{D})$, crops (E and F), and manure ( $\mathrm{G}$ and $\mathrm{H})$. 

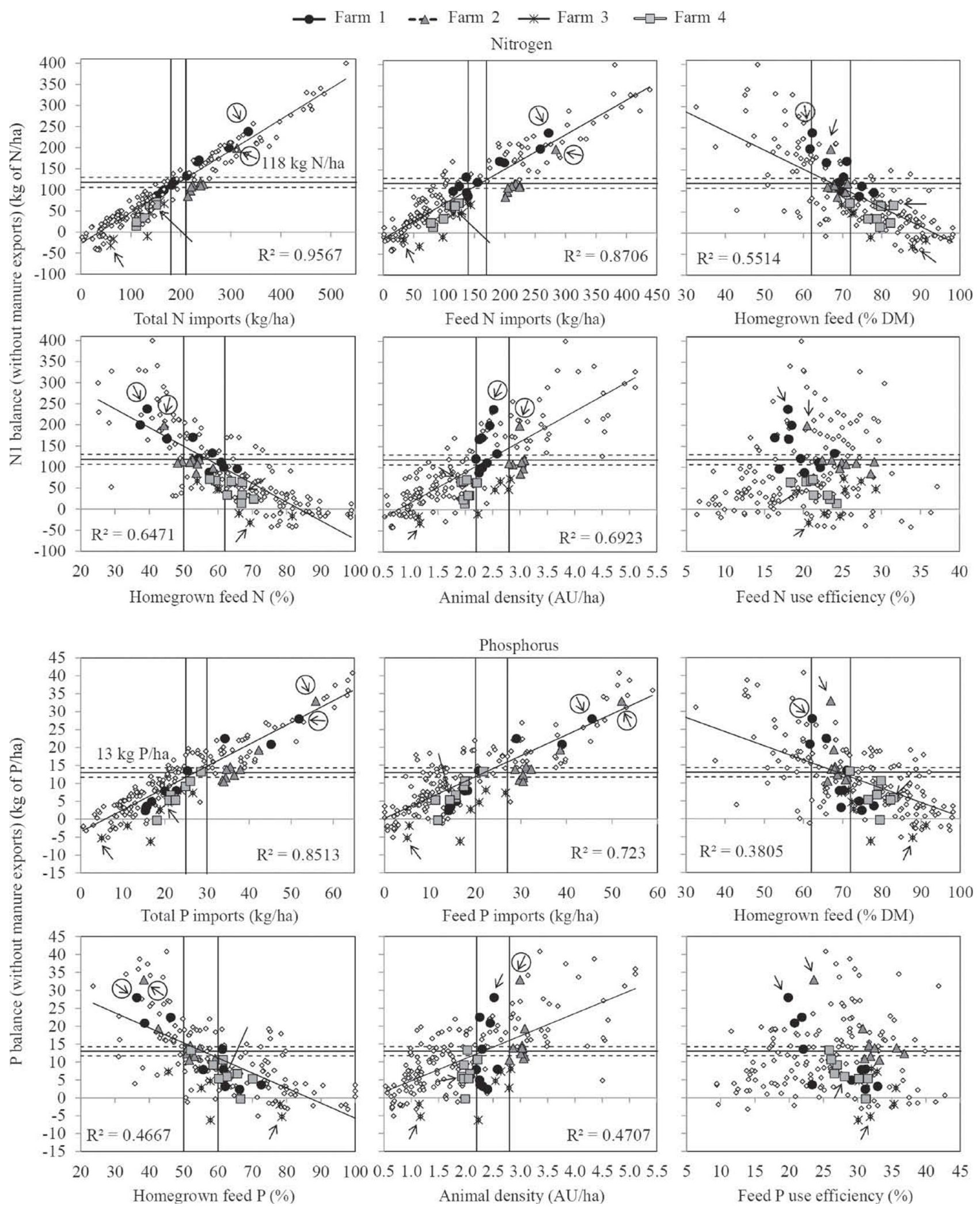

Figure 9. Nitrogen and phosphorus mass balances per hectare (without manure exports) as a function of different indicators for 27 dairy farms in New York over the study period. The horizontal lines indicate the feasible nutrient mass balance (NMB) per hectare defined for New York $\pm 10 \%$. The vertical lines indicate low and high likelihood of exceeding the feasible NMB per hectare. The arrows point at the first year of NMB assessment for each of the 4 selected farms. The circle indicates an area for improvement. 
(4) homegrown $\mathrm{N}$ and $\mathrm{P}$ feed was $>60$ to $62 \%$; and (5) animal density was $<2.2 \mathrm{AU} / \mathrm{ha}$. Thresholds could not be determined for feed use efficiency because of the lack of a clear relationship with NMB.

According to the key indicators in the first $2 \mathrm{yr}$ of NMB assessment, Farm 1 had a high risk of exceeding the feasible NMB per hectare due to (1) a low percentage of homegrown feed and (2) large total and feed $\mathrm{N}$ and $\mathrm{P}$ imports. For Farm 2, key indicators suggested an opportunity to reduce total $\mathrm{N}$ and $\mathrm{P}$ import, and specifically feed $\mathrm{N}$ and $\mathrm{P}$, despite having a reasonable percentage of homegrown feed production. In Farms 3 and 4 , all key indicators suggested low risk of exceeding the feasible NMB, in line with their low NMB, whereas for Farm 3 the negative balances indicated the potential for mining of soil $\mathrm{P}$ and $\mathrm{K}$ consistent with a low animal density combined with low fertilizer use. As such, the indicators of all 4 farms were effective in identifying opportunities for NMB improvements.

The thresholds for animal densities found in our study (low likelihood of exceeding the feasible NMB per hectare if $<2.2 \mathrm{AU} / \mathrm{ha}$, and high likelihood if $>2.8$ $\mathrm{AU} / \mathrm{ha}$ ) are in line with the $2.4 \mathrm{AU} /$ ha threshold suggested by Cela et al. (2014). However, our long-term study also shows that farms with high animal densities, such as Farm 2 (2.8 to $3.1 \mathrm{AU} /$ ha), can operate within the feasible NMB for many years. This was possible because Farm 2 (1) had the highest milk production per cow and per hectare (Figure 1); (2) had the highest overall crop yields, which allowed for feeding relatively high percentages of homegrown feed (66 to 71\%); (3) imported feed with low concentrations of $\mathrm{CP}$ and $\mathrm{P}$ $(<27 \%$ of $\mathrm{CP}$ and $<0.60 \%$ of $\mathrm{P}$ over the last $7 \mathrm{yr}) ;(4)$ imported low amounts of $\mathrm{N}$ fertilizer (on average, $9 \mathrm{~kg}$ of $\mathrm{N} / \mathrm{ha}$, compared with 20 to $41 \mathrm{~kg}$ of $\mathrm{N} / \mathrm{ha}$ on the other 3 farms) and relatively low amounts of $\mathrm{P}$ fertilizer (on average, $3 \mathrm{~kg} \mathrm{P} / \mathrm{ha}$, compared with up to $7 \mathrm{~kg}$ of $\mathrm{P} /$ ha on the other 3 farms); (5) exported crops every year (on average, $7 \mathrm{~kg}$ of $\mathrm{N} / \mathrm{ha}$ and $1 \mathrm{~kg}$ of $\mathrm{P} /$ ha; Figure $8 \mathrm{E}, \mathrm{F}$ ); (6) exported manure during the first $5 \mathrm{yr}$ (on average, $19 \mathrm{~kg}$ of $\mathrm{N} / \mathrm{ha}$ and $3 \mathrm{~kg}$ of $\mathrm{P} / \mathrm{ha}$; Figure 8G, $\mathrm{H})$; and (7) exported more nutrients via animals than the other farms (on average, $16 \mathrm{~kg}$ of $\mathrm{N} / \mathrm{ha}$ and $4 \mathrm{~kg}$ of $\mathrm{P} /$ ha compared with $8 \mathrm{~kg}$ of $\mathrm{N} / \mathrm{ha}$ and $2 \mathrm{~kg}$ of $\mathrm{P} / \mathrm{ha}$ on the other farms; Figure 8C, D).

We concluded that farms that conducted annual NMB over 6 to $10 \mathrm{yr}$ tended to make management changes that improved their NMB and whole-farm nutrient use efficiencies over time, primarily due to changes in feed nutrient imports that increased feed nutrient use efficiency (precision feed management). Overall, the key indicators proposed by Soberon et al. (2015) were effective in providing initial orientation on potential areas for improvement in NMB and to monitor improvement over time. However, results also suggest that other indicators, such as the concentration of nutrients in purchased feed, fertilizer imports per hectare, and the overall crop yield, should be included in the assessments. To identify opportunities for improvements in NMB, total imports, feed imports, the percentage of homegrown feed and homegrown nutrients fed, animal density, fertilizer imports, the percentage of $\mathrm{CP}$ and $\mathrm{P}$ in the purchased feed, and the overall crop yield should be evaluated as key indicators.

\section{ACKNOWLEDGMENTS}

We thank all the farmers, Soil and Water Conservation District and NRCS staff, Cornell Cooperative Extension educators, and consultants that participated in this study. This work was supported by grants from Northeast Sustainable Agriculture Research and Extension (NESARE), Northern New York Agricultural Development Program (NNYADP), Federal-Formula Funds, and USDA-NRCS.

\section{REFERENCES}

Anderson, B. H., and F. R. Magdoff. 2000. Dairy farm characteristics and managed flows of phosphorus. Am. J. Altern. Agric. 15:19-25.

Cela, S., Q. M. Ketterings, K. Czymmek, M. Soberon, and C. Rasmussen. 2014. Characterization of nitrogen, phosphorus, and potassium mass balances of dairy farms in New York State. J. Dairy Sci. 97:7614-7632.

Cerosaletti, P. E., D. G. Fox, and L. E. Chase. 2004. Phosphorus reduction through precision feeding of dairy cattle. J. Dairy Sci. 87:2314-2323.

Gourley, C. J. P., W. J. Dougherty, D. M. Weaver, S. R. Aarons, I. M. Awty, D. M. Gibson, M. C. Hannah, A. P. Smith, and K. I. Peverill. 2012. Farm-scale nitrogen, phosphorus potassium and sulfur balances and use efficiencies on Australian dairy farms. Anim. Prod. Sci. 52:929-944.

Hristov, A. N., W. Hazen, and J. W. Ellsworth. 2006. Efficiency of use of imported nitrogen, phosphorus, and potassium and potential for reducing $\mathrm{P}$ imports on Idaho dairy farms. J. Dairy Sci. 89:3702-3712.

Ketterings, Q. M. 2013. Extension and knowledge transfer: Adaptive management approaches for timely impact. J. Agric. Sci. 152:5764. http://dx.doi.org/10.1017/S002185961300066X.

Ketterings, Q. M., and K. J. Czymmek. 2012. Phosphorus index as a phosphorus awareness tool: Documented phosphorus use reduction in New York State. J. Environ. Qual. 41:1767-1773.

Ketterings, Q. M., G. S. Godwin, S. N. Swink, and K. J. Czymmek. 2013. Can manure replace the need for starter nitrogen fertilizer? Agron. J. 105:1597-1605.

Ketterings, Q. M., S. N. Swink, G. Godwin, K. J. Czymmek, and G. L. Albrecht. 2005. Maize silage yield and quality response to starter phosphorus fertilizer in high phosphorus soils in New York. J. Food Agric. Environ. 3:237-242.

Kohn, R. A., Z. Dou, J. D. Ferguson, and R. C. Boston. 1997. A sensitivity analysis of nitrogen losses from dairy farms. J. Environ. Manage. 50:417-428.

Natural Resources Conservation Service (NRCS). 2013. Adaptive Nutrient Management Process. Agronomy Technical Note No. 7. NRCS, USDA, Washington, DC. Accessed Feb. 24, 2015. http://directives. sc.egov.usda.gov/OpenNonWebContent.aspx? content=33791. wba.

Nevens, F., I. Verbruggen, D. Reheul, and G. Hofman. 2006. Farm gate nitrogen surpluses and nitrogen use efficiency of specialized 
dairy farms in Flanders: Evolution and future goals. Agric. Syst. 88:142-155.

New York Agricultural Statistics Service (NYSASS). 2013. New York Agricultural Statistics 2012-2013 Annual Bulletin. USDA National Agricultural Statistics Service New York Field Office, Albany, NY. Accessed Dec. 12, 2014. http://www.nass.usda.gov/ Statistics_by_State/New_York/Publications/Annual_Statistical_ Bulletin/2013/2013-bulletin.htm.

New York NRCS USDA. 2005. Feed Management (592). New York NRCS Field Office Technical Guide (eFOTG). Accessed Feb. 24, 2015. ftp://ftp.dec.state.ny.us/dow/Chesapeake\%20 Record $/ 2010 \% 20$ NRCS\% 20Standards\%20in $\% 20$ New $\% 20$ York $/ 592 \% 20$ FeedManagment\%28NY592\%29.pdf.

NRC. 2001. Nutrient Requirements of Dairy Cattle. 7th rev. ed. Natl. Acad. Press, Washington, DC.

Oenema, O., H. Kros, and W. de Vries. 2003. Approaches and uncertainties in nutrient budgets: implications for nutrient management and environmental policies. Eur. J. Agron. 20:3-16.

SAS Institute. 2013. The SAS System for Windows. Version 9.3 SAS Inst. Inc., Cary, NC.
Soberon, M., S. Cela, Q. M. Ketterings, K. J. Czymmek, and C. Rasmussen. 2015. Changes in nutrient mass balances over time and drivers for change for 54 New York dairy farms. J. Dairy Sci. 98:5313-5350.

Soberon, M. A., Q. M. Ketterings, C. N. Rasmussen, and K. J. Czymmek. 2013. Whole-farm nutrient balance calculator for New York dairy farms. Nat. Sci. Educ. 42:57-67.

Spears, R. A., R. A. Kohn, and A. J. Young. 2003. Whole-farm nitrogen balance on western dairy farms. J. Dairy Sci. 86:4178-4186.

USDA-EPA (Environmental Protection Agency). 1999. Unified National Strategy for Animal Feeding Operations. USDA-EPA, Washington, DC.

USDA-ERS (Economic Research Service). 2014. Trade. Soybeans and oil crops: Canola. Accessed Dec. 17, 2014. http://www.ers.usda. gov/topics/crops/soybeans-oil-crops/canola.aspx\#trade.

USDA-NASS (National Agricultural Statistics Service). 2014. Milk production historic data. USDA-NASS, Washington, DC Accessed Oct. 24, 2014. http://www.nass.usda.gov/Statistics by_State/New_York/Historical_Data/MilkProduction/ MilkProductionIndex.htm. 